\title{
A map-view restoration of the Alpine-Carpathian-Dinaridic system for the Early Miocene
}

\author{
Kamil Ustaszewski ${ }^{1, *}$, Stefan M. Schmid ${ }^{1}$, Bernhard FÜgenschuH ${ }^{1,2}$, MatThias TischleR ${ }^{1, * *}$, \\ EDUARD KISSLING $^{3} \&$ WIM SPAKMAN ${ }^{4}$
}

Key words: Tectonics, kinematics, palinspastic restoration, Alps, Carpathians, Dinarides, Adriatic plate

\begin{abstract}
A map-view palinspastic restoration of tectonic units in the Alps, Carpathians and Dinarides reveals the plate tectonic configuration before the onset of Miocene to recent deformations. Estimates of shortening and extension from the entire orogenic system allow for a semi-quantitative restoration of translations and rotations of tectonic units during the last $20 \mathrm{Ma}$. Our restoration yielded the following results: (1) The Balaton Fault and its eastern extension along the northern margin of the Mid-Hungarian Fault Zone align with the Periadriatic Fault, a geometry that allows for the eastward lateral extrusion of the Alpine-Carpathian-Pannonian (ALCAPA) Mega-Unit. The Mid-Hungarian Fault Zone accommodated simultaneous strike-perpendicular shortening and strike-slip movements, concomitant with strike-parallel extension. (2) The Mid-Hungarian Fault Zone is also the locus of a former plate boundary transforming opposed subduction polarities between Alps (including Western Carpathians) and Dinarides. (3) The ALCAPA Mega-Unit was affected by $290 \mathrm{~km}$ extension and fits into an area W of present-day Budapest in its restored position, while the Tisza-Dacia Mega-Unit was affected by up to $180 \mathrm{~km}$ extension during its emplacement into the Carpathian embayment.
\end{abstract}

(4) The external Dinarides experienced Neogene shortening of over $200 \mathrm{~km}$ in the south, contemporaneous with dextral wrench movements in the internal Dinarides and the easterly adjacent Carpatho-Balkan orogen. (5) N-S convergence between the European and Adriatic plates amounts to some $200 \mathrm{~km}$ at a longitude of $14^{\circ} \mathrm{E}$, in line with post-20 Ma subduction of Adriatic lithosphere underneath the Eastern Alps, corroborating the discussion of results based on high-resolution teleseismic tomography.

The displacement of the Adriatic Plate indenter led to a change in subduction polarity along a transect through the easternmost Alps and to substantial Neogene shortening in the eastern Southern Alps and external Dinarides. While we confirm that slab-pull and rollback of oceanic lithosphere subducted beneath the Carpathians triggered back-arc extension in the Pannonian Basin and much of the concomitant folding and thrusting in the Carpathians, we propose that the rotational displacement of this indenter provided a second important driving force for the severe Neogene modifications of the AlpineCarpathian-Dinaridic orogenic system.

\section{Introduction}

\subsection{Plate tectonic setting}

The Alps, Carpathians and Dinarides form a topographically continuous, yet highly curved orogenic belt, which bifurcates and encircles the Pannonian Basin. They are part of the much larger system of Circum-Mediterranean orogens (Fig. 1). Despite such a continuous topographic expression, this orogenic system is characterised by dramatically diachronous deformation stages along-strike. Its various parts comprise different paleogeographic domains, and major thrusts have opposing polarity (Schmid et al. 2008): in the Western and Eastern Alps as well as in the Carpathians thrusts face the European foreland, whereas in the Southern Alps and the Dinarides thrusts face the Adriatic foreland. In a pioneering article, Laubscher (1971) suggested that the Alps and the Dinarides owe their different structural facing to opposing subduction polarities. Deep reflection seismic profiling and seismic tomography have since shown that the western and central segments of the Alps are underlain by a south-dipping lithospheric slab, attributed to subducted European lower lithosphere (Schmid et al. 1996, 2004a; Schmid \& Kissling 2000), whereas the Dinarides and Hellenides are underlain by a northeast-dipping lithospheric

\footnotetext{
${ }^{1}$ Institute of Geology and Palaeontology, Bernoullistrasse 32, University of Basel, CH-4056 Basel.

${ }^{2}$ Institute of Geology and Palaeontology, University of Innsbruck, A-6020 Innsbruck.

${ }^{3}$ Institute of Geophysics, ETH Hönggerberg, CH-8093 Zürich, Switzerland.

${ }^{4}$ Faculty of Geosciences, Utrecht University, NL-3508 Utrecht, Netherlands.

*Corresponding author, now at: Department of Geosciences, National Taiwan University, No. 1, Sec. 4, Roosevelt Road, Taipei, 10617 Taiwan.

E-mail: kamilu@ntu.edu.tw, Tel: +886-2-23636450 \#205

**Now at: StatoilHydro ASA, 4035 Stavanger, Norway.
} 
slab (e.g. Wortel \& Spakman 2000; Piromallo \& Morelli 2003) south of $44^{\circ} \mathrm{N}$.

Recent studies suggest that a northeast-dipping "Adriatic" lithospheric slab of about $200 \mathrm{~km}$ length also underlies the Eastern Alps in the area east of the Giudicarie and Brenner Fault (Lippitsch et al. 2003; Kissling et al. 2006). Schmid et al. (2004b) and Kissling et al. (2006) tentatively proposed that this slab is a remnant of Palaeogene orogeny in the Dinarides, which impinged onto the Alps during the Neogene by a combination of northward motion of the Adriatic plate indenter and dextral wrench movement along the Periadriatic Fault. This was a speculative assignment, however, since there is no geophysical evidence for a continuous, northeast-dipping Adriatic lithospheric slab between the Eastern Alps and the Dinarides north of $44^{\circ} \mathrm{N}$ (Piromallo \& Morelli 2003; this study).
In this contribution we present in map-view a palinspastic restoration of the substantial displacements and rotations the various tectonic mega-units of the Alpine-Carpathian-Dinaridic orogenic system underwent during the last $20 \mathrm{Ma}$ (e.g. Balla 1987), providing better insight into their early Neogene configuration. We propose that the Mid-Hungarian Fault Zone (Fig. 2) originated from a transform fault, across which the subduction polarity changed from the Alpine to the Dinaridic polarity. Furthermore, our restoration implies c. $200 \mathrm{~km}$ of $\mathrm{N}-\mathrm{S}$ shortening between the Adriatic and European plates, in line with the estimated length of the northeast-dipping slab (Lippitsch et al. 2003). This suggests that this slab represents Adriatic lithosphere that was subducted since the early Neogene. Based on this interpretation, we discuss possible reasons for the current discontinuity of the northeastdipping slab between the Eastern Alps and the Dinarides.
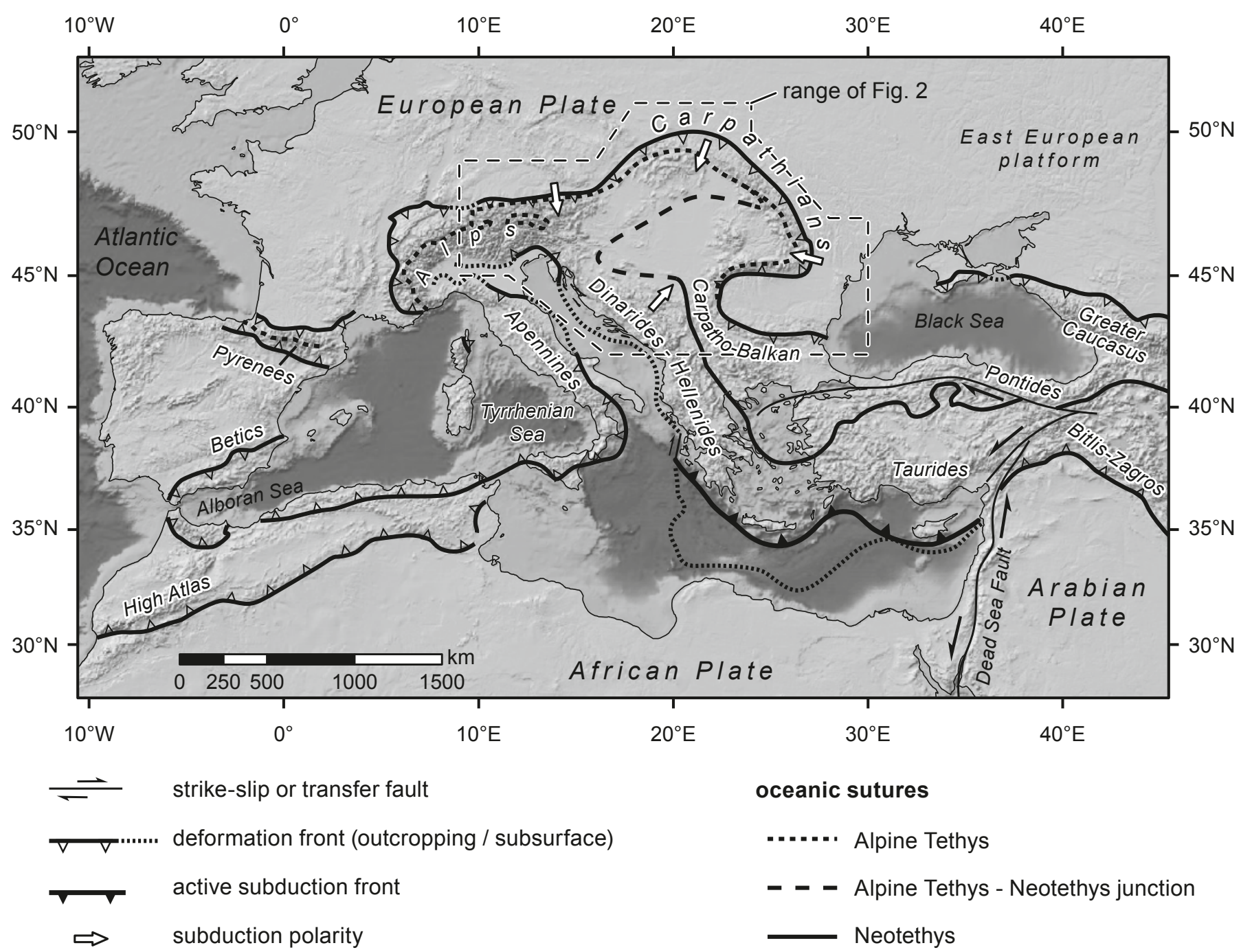

oceanic sutures

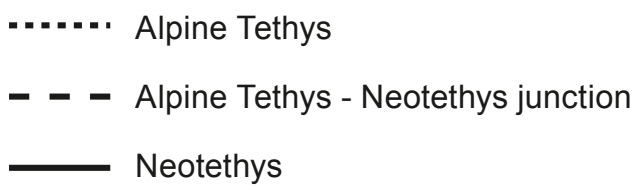

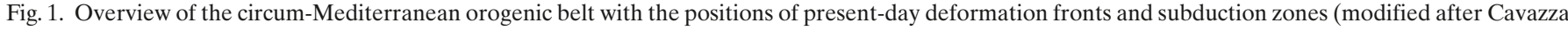

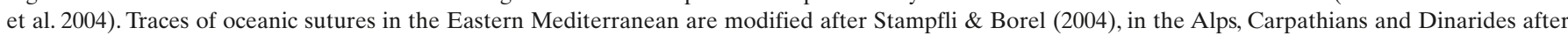

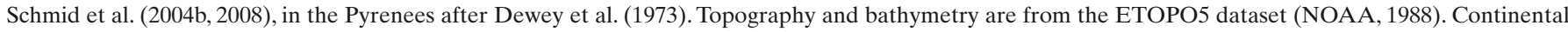

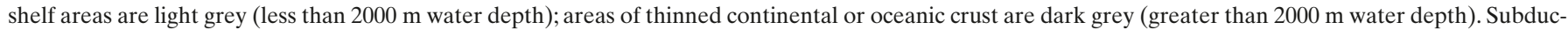
tion polarities are only shown for the range of Fig. 2 . 


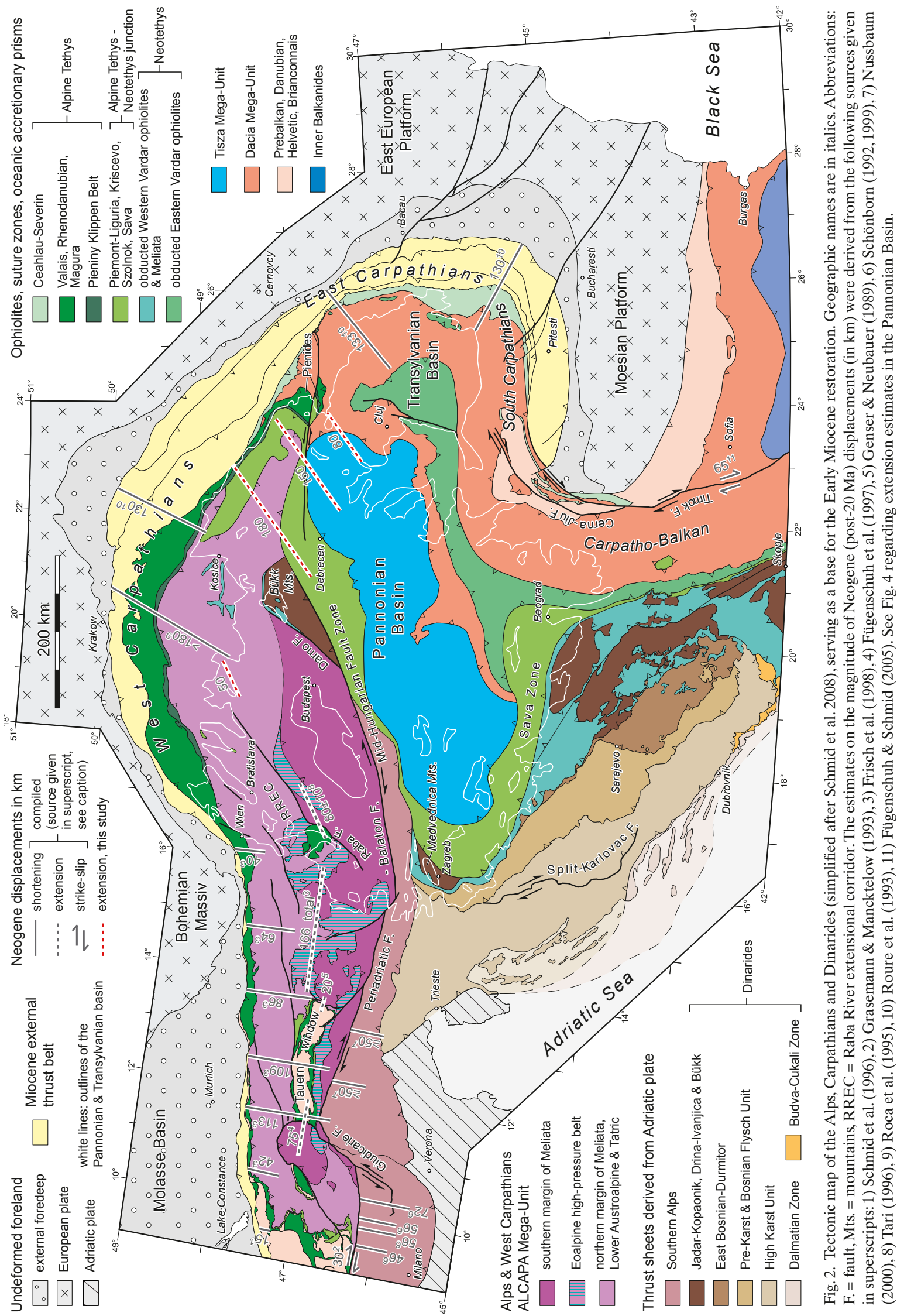




\subsection{Previous work}

The eye-catching oroclinal architecture of the Alps, Carpathians and Dinarides has since long inspired map-view retrodeformations that improved our understanding of the pre-collisional plate tectonic assemblage (e.g. Channell \& Horváth 1976). Burchfiel (1980) demonstrated that many of the continental fragments involved underwent significant shortening during the Mesozoic to Cenozoic convergence of Europe and the Apulia/Adria promontory. However, the substantial extension, which the ALCAPA (Csontos \& Vörös 2004; Schmid et al. 2008) and Tisza-Dacia mega-units underwent in the Late Cretaceous (Froitzheim et al. 1997) and particularly in the Neogene during their emplacement into the Carpathian embayment, remained unaccounted for. As a mega-unit we define an assembly of tectonic units, which as a whole has a common paleogeographic origin that is distinct from adjacent tectonic units or other mega-units, from which it is separated by faults. In contrast to a microplate, its original lithospheric underpinnings are either lacking or unknown. Hence, this definition is a somewhat more loose definition of a terrane, which implies that a crustal allochthon was separated from its own lithospheric mantle underpinnings via accretion to a larger plate. Also, the term mega-unit complies with its frequent usage in the regional geological literature (see e.g. Haas 2001; Haas \& Pero 2004).

Based on paleomagnetic data, Balla (1987) showed that the ALCAPA and the Tisza-Dacia mega-units north and south of the Mid-Hungarian Fault Zone, respectively, floor the area that is presently occupied by the Pannonian Basin (e.g. Csontos \& Nagymarosy 1998; Tischler et al.2007). Starting in the late Early Miocene, these fragments experienced opposed sense rotations during their emplacement into the Carpathian embayment (see Fig. 7 in Balla 1987). Subsequent palinspastic restorations (e.g. Royden \& Baldi 1988; Csontos et al. 1992; Csontos 1995; Fodor et al. 1999; Csontos \& Vörös 2004) generally built on Balla (1987). Many of these studies took paleomagnetic constraints on the rotations of tectonic units rather quantitatively into account, whilst the translation and concomitant deformation of these units was only qualitatively treated.

Another set of palinspastic restorations aimed at restoring tectonic units based on the quantification of shortening amounts derived from balanced cross sections or from restoring offsets along major strike-slip faults. Two such examples are Frisch et al. (1998) and Linzer et al. (2002), who provided a palinspastic restoration of the Eastern Alps for Late Oligocene to Miocene times. Roure et al. (1993), Ellouz \& Roca (1994), Roca et al. (1995), Morley (1996) and Behrmann et al. (2000) provided estimates of amounts of shortening in the Carpathian thrust belt based on balanced cross-sections. Except for Morley (1996), however, most previous studies did not consider the system of the Alps-Dinarides-Carpathians and the Pannonian Basin in its entirety and hence failed to link its evolution to the role played by the rigid Adriatic indenter during Miocene to recent times.

\section{Rationale for a 20 Ma restoration}

We aim at a semi-quantitative palinspastic restoration of the Early Miocene tectonic configuration, based on a recently compiled new tectonic map (Fig. 2) of the Alpine-CarpathianDinaridic orogenic system (Schmid et al. 2008). We chose the $20 \mathrm{Ma}$ timeframe for our restoration, as this time roughly corresponds to the onset of numerous interrelated tectonic events (Fig. 3), which are briefly reviewed in the following.

1) The E-directed lateral extrusion (escape and concomitant extension) of the Austroalpine units into the Pannonian Basin (Ratschbacher et al. 1991) lasted from about 23 to $13 \mathrm{Ma}$ according to Frisch et al. (1998). A younger (20 Ma) age for the time of onset of this event was inferred from mineral cooling and fission track ages obtained across low angle normal faults that exhumed Lower Austroalpine and Penninic series during this extrusion (e.g. the age of the Brenner normal fault; von Blanckenburg et al. 1989; see also Fügenschuh et al. 1997 and references therein). This is roughly in line with the 18-15 Ma age range of Ottnangian to Badenian sediments that accumulated in intra-montane pull-apart basins associated with conjugate strike-slip faults, which evolved during the eastward escape of the Eastern Alps (Strauss et al. 2001; Linzer et al. 2002 and references therein).

2) Shortening in the Southern Alps started between 20 and $17 \mathrm{Ma}$, i.e. contemporaneously with the sinistral offset of the Periadriatic Fault by the Giudicarie Fault system (Schönborn 1992, 1999; Schmid et al. 1996; Stipp et al. 2004) and lasted until the Messinian. The major shortening in the external Southern Alps occurred during Serravallian-Tortonian times (14-7 Ma). By contrast, thrusting of the Austroalpine nappes onto the North Alpine Foreland Molasse Basin had practically ended at around $17 \mathrm{Ma}$ (Linzer et al. 2002 and references therein).

3) Back-arc-extension and related sedimentation in the riftand wrench-related troughs of the Pannonian Basin complex started in Eggenburgian to Ottnangian times (Bérczi et al. 1988; Nagymarosy \& Müller 1988; Horváth \& Tari 1999), i.e. between 20.5 and $17.5 \mathrm{Ma}$ in the time scale of Steininger \& Wessely (1999).

4) Neogene thrusting in the external flysch belt of the West Carpathians (Royden 1988) reached the Dukla and Silesian units of the West Carpathians by Early Burdigalian (Eggenburgian) times (Kováč et al. 1998; Oszczypko 2006), i.e. at about $20 \mathrm{Ma}$. In the East Carpathians, thrusting also initiated at around $20 \mathrm{Ma}$ in the most internal units of the Moldavides (Convolute flysch and Audia-Macla nappes) but reached more external flysch units only by Late Burdigalian times, i.e. at around 17 Ma (Săndulescu 1988; Matenco \& Bertotti 2000). Some authors invoke along-strike younging of orogenic activity (e.g. Jiříček 1979) that supposedly correlates with a general decrease of the ages of calc-alkaline magmatism in the internal Carpathians and the Pannonian

S276 K. Ustaszewski et al. 
Basin from west towards southeast (e.g. Seghedi et al. 1998; Harangi et al.2006). In any case, thrusting continued longer in the East Carpathians (Matenco \& Bertotti 2000). The formation of this most external thrust belt made up of flysch sediments was associated with subduction of a retreating lithospheric slab underneath an upper plate formed by the ALCAPA and Tisza-Dacia mega-units, including the previously accreted Magura flysch, that started at around $20 \mathrm{Ma}$. Note that earlier thrusting affected more internal units only; we discuss here the onset of Neogene thrusting that started to propagate into the external flysch belt and which is widely accepted as being contemporaneous with back-arc extension in the Pannonian Basin (e.g. Royden 1988; Kováč et al. 1998).

5) In the Early Burdigalian (20.5-18.5 Ma) SE-directed thrusting also initiated in more internal units of the Carpathians and led to the formation of the Pienide nappes (northern Romania) due to the collision of the ALCAPA and the Tisza-Dacia mega-units (Săndulescu 1988; Tischler et al. 2007). This thrusting occurred during the initial stages of emplacement of the ALCAPA and Tisza-Dacia mega-units into the Carpathian embayment and was contemporaneous with their soft collision with the European foreland across the external flysch belt (Márton et al. 2007).

\subsection{Premises for Early Miocene palinspastic restoration}

The Early Miocene restoration was performed with respect to a fixed European foreland under the following premises:

1) Changes to the geometric configuration of tectonic units were applied only to those that underwent significant extension or bending around vertical axes during the timeframe under consideration (20-0 Ma), namely the ALCAPA and Tisza-Dacia mega-units.

2) In areas of shortening the outlines of tectonic units, which are separated by major thrusts were left unchanged. Consequently, gaps opening between the restored and actual position of such individual units permit to assess the amount of shortening those areas underwent during the last $20 \mathrm{Ma}$.

3) The foreland was considered as non-deformed, thus retaining a fixed geometric configuration. The undeformed European foreland (including the external foredeep) served as a fixed reference frame, the position of which remained unchanged. Based on geological arguments it was assumed that the Adriatic Plate behaved as a rigid block that was subjected to translation and rotation only.

4) Magnitudes of shortening, extension and strike-slip displacements were compiled from published sources (Figs. 2 and 4). These data underlay our basic palinspastic restoration of the area of interest. Such data are strictly distinguished from deformations that had to be applied for pure 2-D compatibility reasons in areas that are not or ill-constrained by data. To a large extent the latter are a result of our restoration.
5) Rotations were applied to tectonic units only as required from the following map-view geometric and kinematic arguments: (i) along-strike shortening gradients, (ii) restoration of displacements along curved strike-slip faults and (iii) geometric adjustments to the regional strike. We emphasise that paleomagnetically constrained rotations were not considered as input to our restoration, except for a few small blocks. This was done deliberately in order to test whether a purely kinematic approach yields results that are qualitatively compatible with the paleomagnetic data (e.g. Márton et al. 2003, 2007).

\subsection{Database}

Our palinspastic restoration of the Alpine-Carpathian-Dinarides domain (Figs. 2 and 6) integrated the results of a number of earlier published studies to which we refer below. For the Alpine part of the ALCAPA Mega-Unit we used the restoration by Frisch et al. (1998), which we combined with data from Burkhard \& Sommaruga (1998), Fügenschuh et al. (1997), Genser \& Neubauer (1989), Grasemann \& Mancktelow (1993), Gratier et al. (1989), Lickorish \& Ford (1998), Philippe et al. (1996), Ratschbacher et al. (1991), Schmid et al. (1996), Schönborn (1992, 1999), Nussbaum (2000) and Stipp et al. (2004). Estimates on the magnitude and direction of extension in the eastern (Pannonian Basin) part of ALCAPA were mainly adopted from Tari (1996), and also from Fodor et al. (1998) and Szafián et al. (1999). In addition, we used the crustal thinning factor map for the Pannonian Basin by Lenkey (1999) to estimate the magnitude of extension affecting the ALCAPA and Tisza parts of the Pannonian Basin. For the West Carpathians, we took the restorations by Roure et al. (1993), Roca et al. (1995), Morley (1996) and Behrmann et al. (2000) into consideration for estimating the total shortening that was achieved in the Miocene external thrust belt. These data permitted us to constrain the position of the most external edge of ALCAPA. Furthermore, we used the restorations by Tischler (2005) and Márton et al. (2007) for restoring the boundary area between the ALCAPA and Tisza-Dacia mega-units.

Concerning the Tisza-Dacia Mega-Unit we incorporated a restoration of the South Carpathians bend zone that was proposed by Fügenschuh \& Schmid (2005) and that is essentially based on data by Balla (1987), Berza \& Draganescu (1988), Berza \& Iancu (1994), Kounov et al. (2004), Kräutner \& Krstić (2006), Matenco et al. (1997, 2003), Moser (2001), Patrascu et al. 1994, Schmid et al. (1998) and Săndulescu et al. (1978). Fügenschuh \& Schmid (2005) retro-deformed the tectonic unroofing of the Danubian window as well as strike-slip movements along the curved Cerna-Jiu and Timok faults, which delimit the "mobile" Tisza-Dacia Mega-Unit against the stable Moesian promontory. However, this part of our restoration does not fully constrain the Early Miocene location of the frontal tip of the Tisza-Dacia Mega-Unit, since the westernmost part of this unit underwent contemporaneous stretching during its displacement into the Carpathian embayment. Therefore we used 


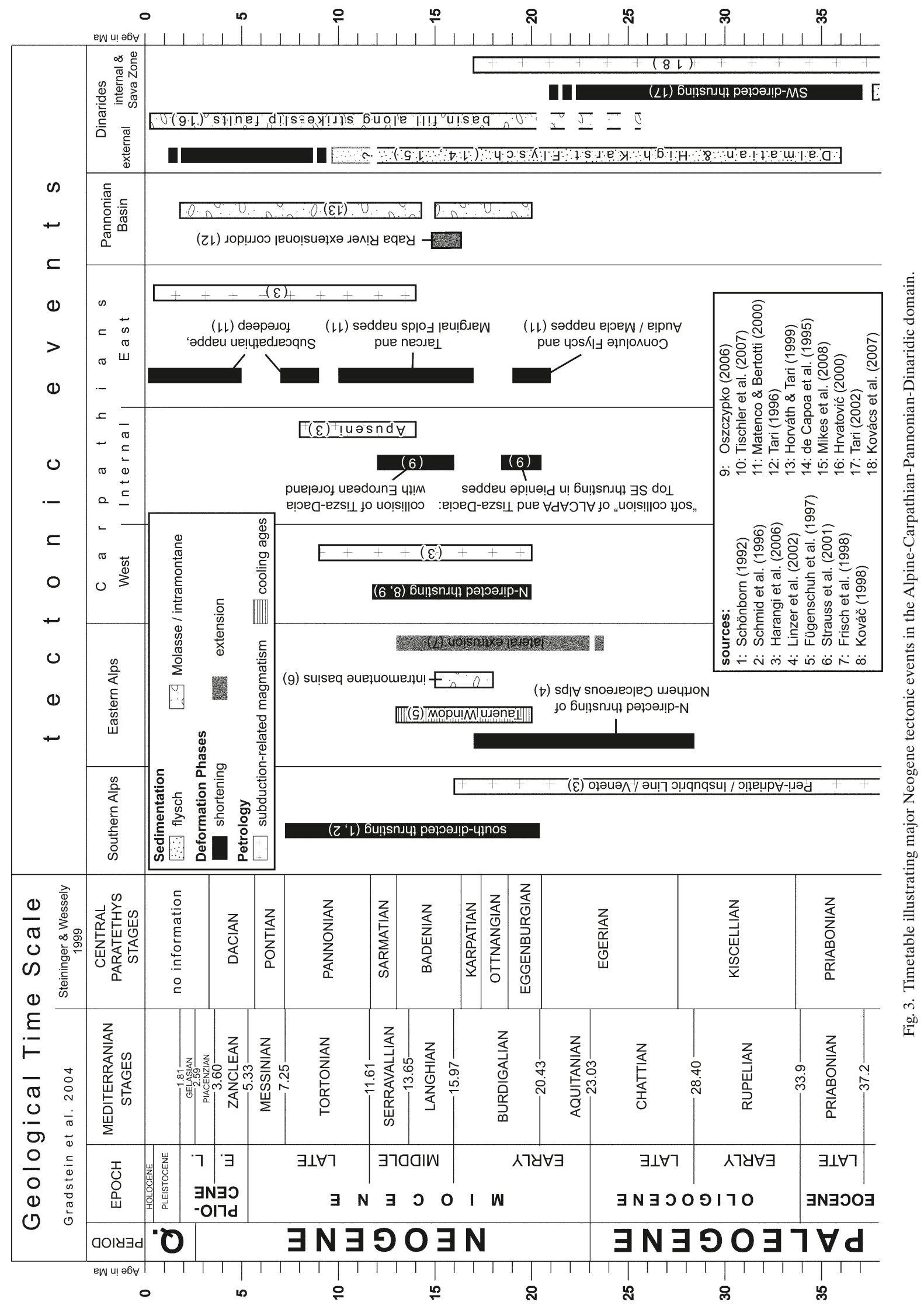

S278 K. Ustaszewski et al. 
the restoration by Morley (1996) in order to anchor the frontal tip of the extending Tisza-Dacia Mega-Unit.

Note that no pre-existing reconstructions or published balanced cross sections could be used as input for the restoration of the Dinarides. The position of the different Dinaridic units was indirectly derived, based on the restoration of the other parts of the orogenic system (see below).

\subsection{Estimating the magnitude of extension in the Pannonian Basin}

In order to restore the tectonic units underlying the Pannonian Basin, estimates of the magnitude and direction of Neogene extension are needed. To this end we adopted the contour map of the crustal thinning factor by Lenkey (1999), which covers the entire Pannonian Basin. This map was calculated by taking into account the present-day depth to the pre-Neogene basement and the heat flow, assuming an initial crustal thickness of $35 \mathrm{~km}$. Lenkey (1999) derived the depth to the pre-Neogene basement from the isopach map of the Neogene sediments in the Pannonian Basin that was published by Horváth and Royden (1981). We also implemented the fault pattern in the Pannonian Basin as given by Horváth (1993) and Horváth et al. (2006).

For our reconstruction we chose five transects that cover the entire Pannonian Basin (A-A' to E-E', Fig. 4). According to Csontos \& Vörös (2004), transects A-A' and B-B' are underlain by the ALCAPA Mega-Unit and trend parallel to the dominant extension direction (ca. N060 $\mathrm{E}$ ), in which the Rechnitz Window core-complex (termed "Raba River extensional corridor" by Tari 1996, "RREC" in Fig. 2) opened, as deduced from ductile transport lineations observed in outcrops from the lower plate of the core complex. Transect A-A' exactly coincides with the cross section of Tari (1996), along which he estimated the amount of extension across the Raba River extensional corridor to amount to $80 \pm 10 \mathrm{~km}$ by correlating footwall (in outcrop) and hangingwall cut-offs (in subsurface, see Figs. $4 \mathrm{~b}$ and 7 in Tari 1996). Transect B-B' was chosen parallel to $\mathrm{A}-\mathrm{A}^{\prime}$, but is offset to the north by some $15 \mathrm{~km}$. It covers the largest Neogene depocenter of the Little Hungarian Plain. Thus the combined transects $\mathrm{A}-\mathrm{A}^{\prime}$ and $\mathrm{B}-\mathrm{B}$ ' traverse the entire northwestern part of the Pannonian Basin along the known extension direction.

Transects $\mathrm{C}-\mathrm{C}^{\prime}$ to $\mathrm{E}-\mathrm{E}^{\prime}$, each of them traversing the entire Pannonian Basin, are underlain by the Tisza-Dacia Mega-Unit (e.g. Csontos \& Vörös 2004). Also these transects were constructed parallel to the dominant extension direction during the Karpatian-Badenian synrift phase, as derived from basinwide kinematic analyses of fault-slip data (ca. N050 ${ }^{\circ}$ E; Fodor et al. 1999).

While along transect $\mathrm{A}-\mathrm{A}^{\prime}$ the magnitude of extension was adopted from Tari (1996), we need to discuss below how we estimated extension along transects B-B' to E-E'. These four transects traverse numerous normal faults. We subdivided these transects at their intersection points with normal faults into several segments $i$, which are characterised by variable crustal thinning factors. For each transect segment we estimated the magnitude of extension as follows:

$l_{0}=\frac{l_{1}}{\delta}$

where $l_{0}$ is the initial length of a segment prior to extension, $l_{1}$ its present-day length after extension and $\delta$ the crustal thinning factor as given by Lenkey (1999). Once $l_{0}$ was obtained for each transect segment, the magnitude of extension $d l$ (length change) along each segment could be estimated:

$d l=l_{1}-l_{0}$

Along a given transect, the total amount of extension $d l_{\text {tot }}$ was calculated by summing up the incremental length changes $d l$ along its constituent segments $i$ :

$d l_{\text {tot }}=\sum d l_{i}$

This approach yielded highly variable magnitude of extension for the four transects under consideration (combined transects $\mathrm{A}-\mathrm{A}^{\prime}, \mathrm{B}-\mathrm{B}^{\prime}$ and transects $\mathrm{C}-\mathrm{C}^{\prime}, \mathrm{D}-\mathrm{D}^{\prime}$ and $\mathrm{E}-\mathrm{E}^{\prime}$ ), ranging from about $78 \mathrm{~km}$ for transect $\mathrm{E}-\mathrm{E}^{\prime}$ to $180 \mathrm{~km}$ for transect $\mathrm{C}-\mathrm{C}^{\prime}$ (Fig. 4). Results of this analysis suggest that the magnitude of extension is largest in the central parts of the Pannonian $\mathrm{Ba}-$ sin that are closely associated with the Mid-Hungarian Fault Zone. In the following, we will implement these estimates of the amount and direction of extension in our Early Miocene restoration of the geometry and position of the ALCAPA and Tisza-Dacia mega-units.

\subsection{Restoring the ALCAPA Mega-Unit}

Combining the extension values of transects $\mathrm{A}-\mathrm{A}^{\prime}$ and $\mathrm{B}-\mathrm{B}^{\prime}$ (Fig. 4) yields a net extension of $130 \pm 10 \mathrm{~km}$ for the northwestern part of the Pannonian Basin, which is floored by the eastern parts of the ALCAPA Mega-Unit. Combined with $160 \mathrm{~km}$ of extension in the Eastern Alps (Frisch et al. 1998), this totals to $290 \pm 10 \mathrm{~km}$ of overall extension that affected ALCAPA during the Neogene. This value was used to restore the Early Miocene outlines of ALCAPA (Fig. 5a). The Raba River extensional corridor, bounded to the west by the Raba River Fault, is mainly responsible for the Neogene exhumation of the Lower Austroalpine, Tatric and Valais units below higher tectonic units (Fig. 2; for more details see Plate 1 in Schmid et al. 2008). This extensional corridor is located exactly at the longitude, where the E-W-strike of the Eastern Alps turns into the NE-strike of the West Carpathians. The available time constraints (Fig. 3) show that shortening in the Miocene thrust belt of the West Carpathians started earlier and lasted longer (Eggenburgian to Sarmatian) than core complex formation in the Raba River extensional corridor (Karpatian to Early Badenian). Kinematically this implies that the eastern part of the ALCAPA MegaUnit underwent a counter-clockwise rotation prior, during and after its extensional deformation. 


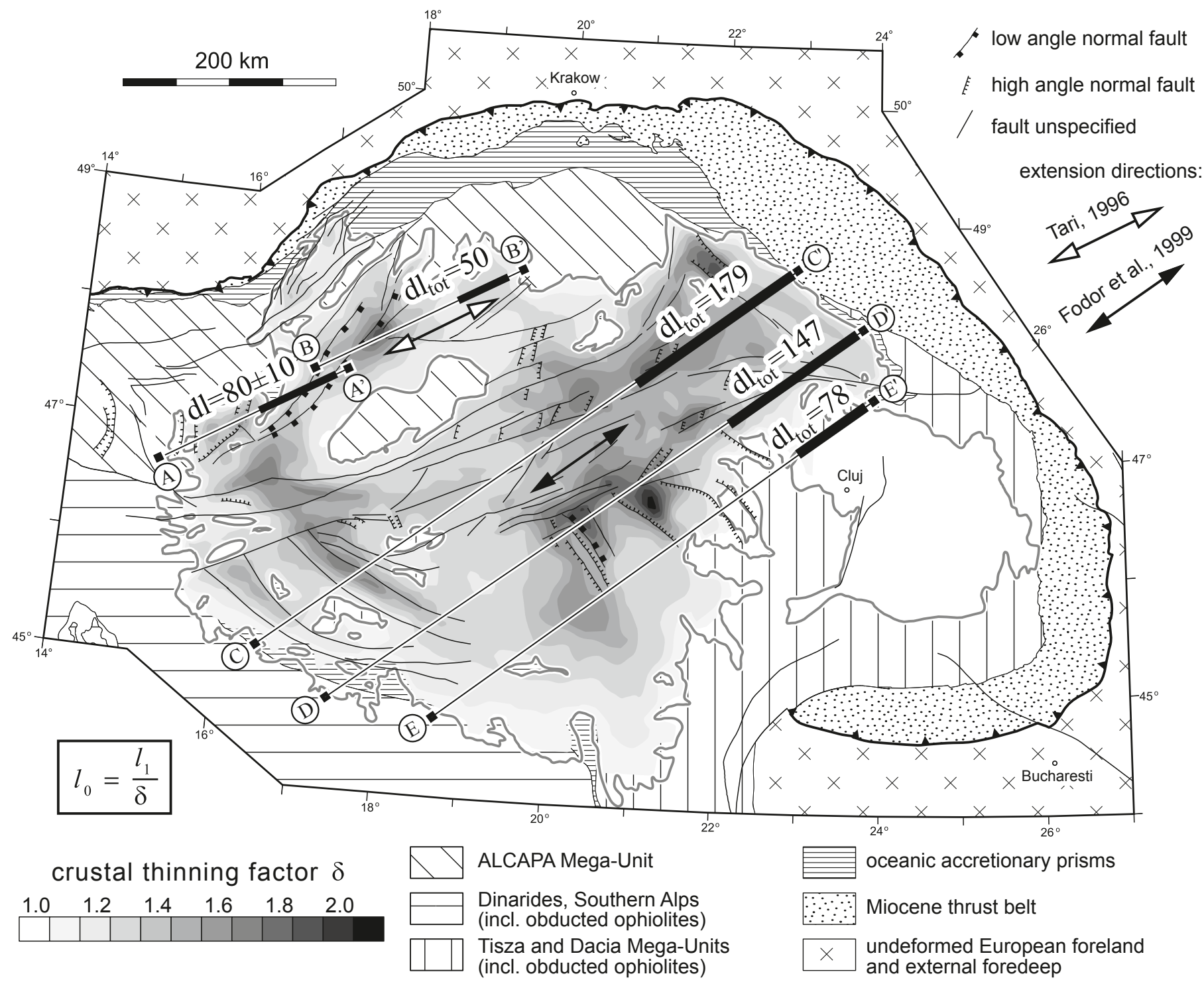

Fig. 4. Estimates on the extension amount in the Pannonian Basin. Fault pattern in the Pannonian Basin was adopted from Horváth (1993). The contour map of the crustal stretching factor is taken from Lenkey (1999). All thrusts except the most external one are omitted for reasons of legibility.

In order to restore geometry and location of the eastern parts of ALCAPA prior to rotation, a $23^{\circ}$ clockwise rotation around a pivot point located at the SW tip of the Raba River Fault was applied to ALCAPA. Such a rotation leads to a linear striking Rhenodanubian - Magura Flysch Belt and results in a position of the northern edge of ALCAPA that is in agreement with previous studies (Morley 1996; Behrmann et al. 2000; Fig. 5a). Moreover, this rotation also straightens out the Periadriatic Fault and its extension into Hungary (Fodor et al. 1998). We consider the Darno Fault, which separates ALCAPA from the Bükk Mountains, to represent part of the Periadriatic Fault (Schmid et al. 2008). We applied an additional $30^{\circ}$ clockwise rotation (i.e. $23+30=53^{\circ}$ ) to the Bükk Mountains in order to align the Darno Fault along-strike with the main trend of the Periadriatic Fault.
In a next step, the eastern margin of ALCAPA was translated westward along a roughly E-W-trending trajectory by c. $280-300 \mathrm{~km}$, corresponding to the extension value arrived at by the above described estimates. The available time constraints suggest that at $20 \mathrm{Ma}$ the easternmost tip of ALCAPA was just getting in contact with the Tisza-Dacia Mega-Unit, as evidenced by Burdigalian SE-directed thrusting in the Pienides (Tischler et al. 2007; Márton et al. 2007).

\subsection{Restoring the Tisza-Dacia Mega-Unit}

For those parts of the Pannonian Basin, which are floored by the Tisza-Dacia Mega-Unit, extension values appear to decrease systematically SE-ward away from the Mid-Hungarian Fault Zone towards the un-extended Transylvanian 

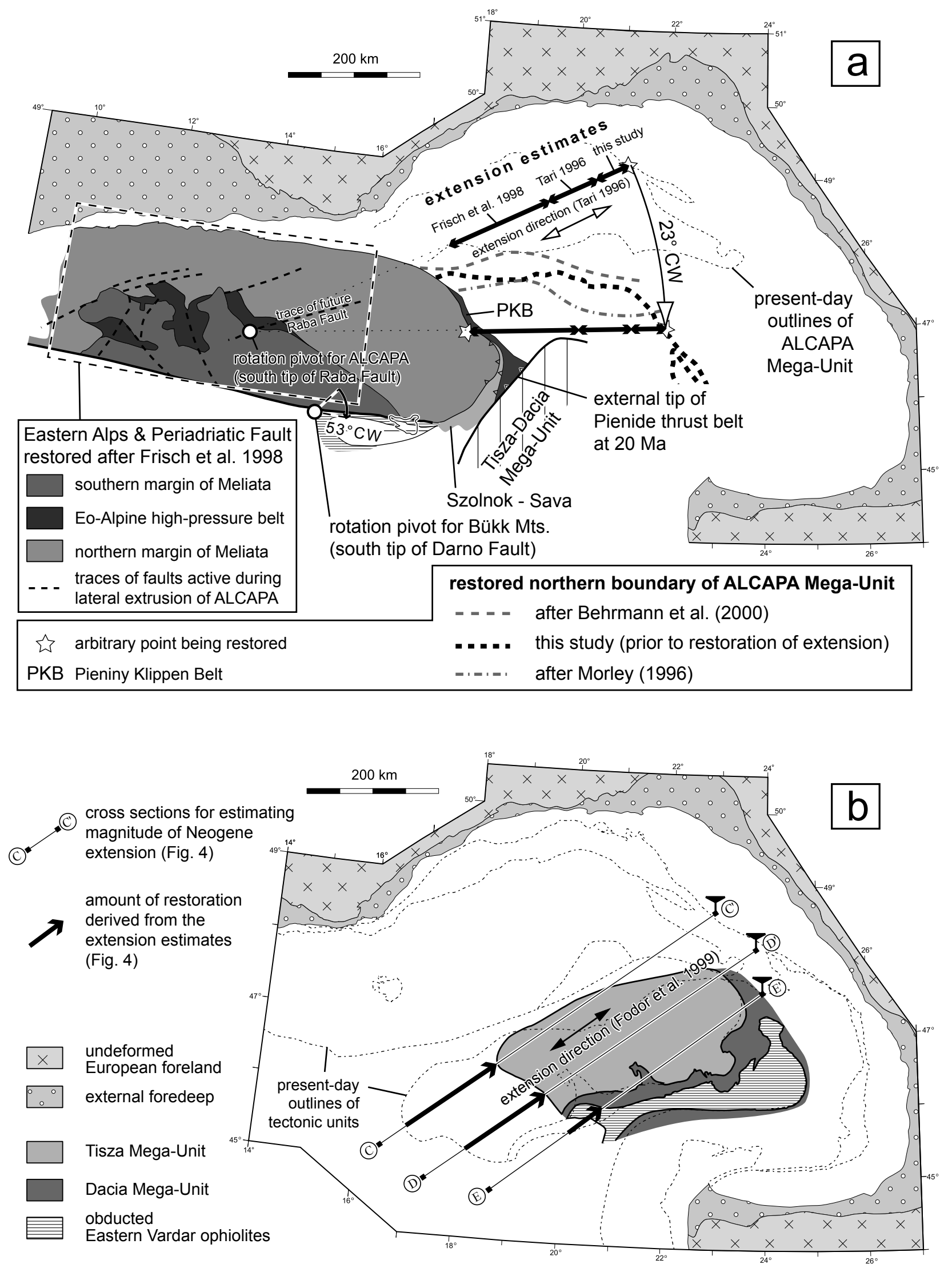

Fig. 5. Reconstruction of (a) the ALCAPA and (b) Tisza-Dacia mega-units according to the constraints described in the text. 


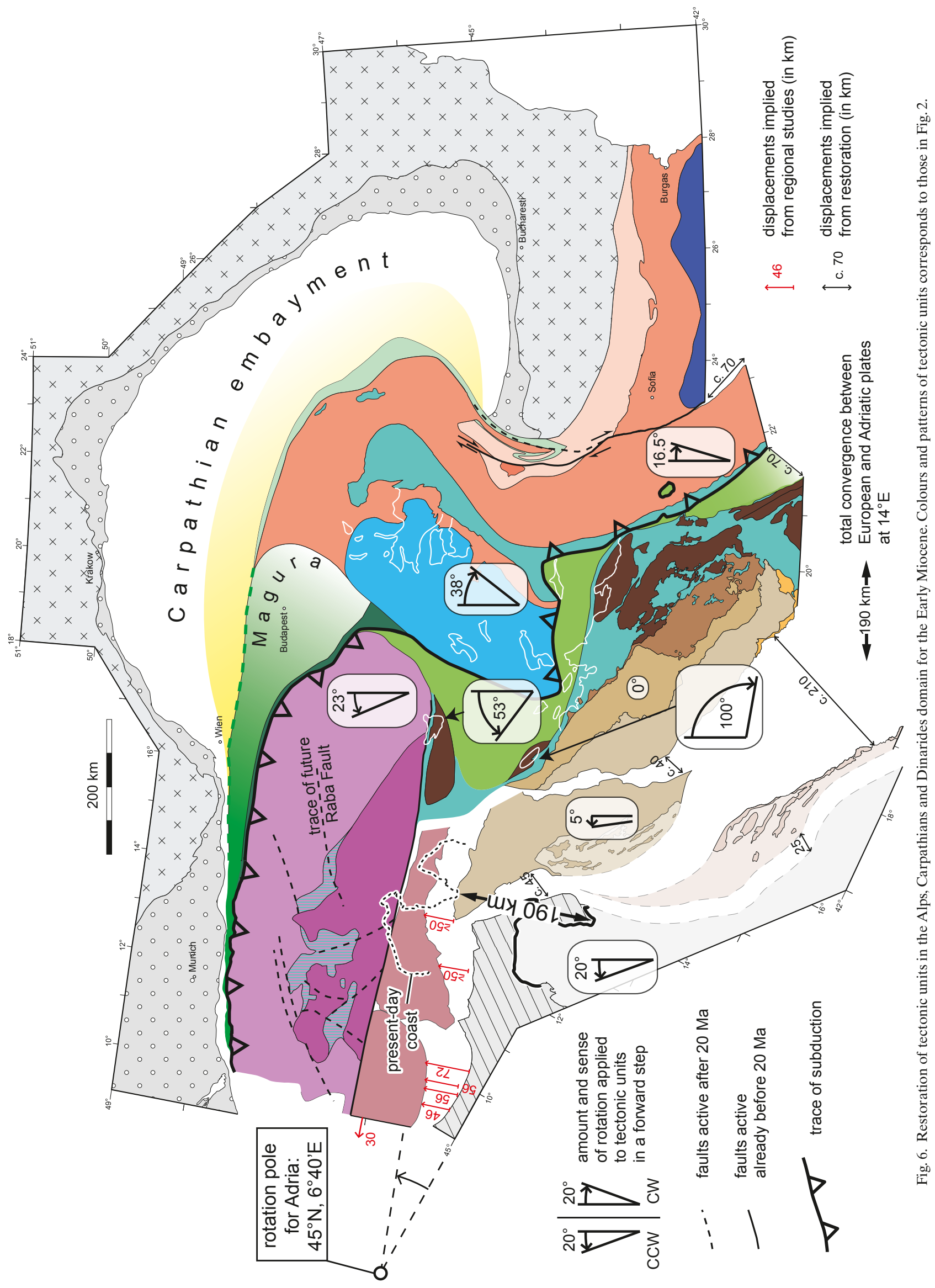


Basin (Krézsek \& Bally 2006) and the Moesian Foreland (Fig. 4). This is also compatible with the fact that the Neogene fault-bounded basins that affect the northwestern part of the Apuseni Mountains shallow out towards southeast (Săndulescu et al. 1978); this directly indicates decreasing amounts of extension towards SE. The restored configuration of Tisza-Dacia was arrived at by shortening the entire mega-unit along transects $\mathrm{C}-\mathrm{C}^{\prime}$ to $\mathrm{E}-\mathrm{E}$ ' by the corresponding extension values (Fig. 5b).

For reconstructing the position of the external, leading edge of Tisza-Dacia (external with respect to the Carpathian thrust facing) during the Early Miocene, we adopted the restoration of Fügenschuh \& Schmid (2005). This restoration is mainly constrained by retro-deforming $65 \mathrm{~km}$ of dextral strikeslip displacement of the Tisza-Dacia Mega-Unit relative to the Moesian foreland along the curved Timok Fault (see Figure 9c in Fügenschuh \& Schmid 2005; Moser 2001).

\subsection{Restoring the location of the Adriatic Plate}

The Early Miocene position of the Adriatic Plate was reconstructed by retro-deforming 1) the Neogene shortening recorded in the Southern Alps, 2) the Neogene dextral strike slip displacements along the Periadriatic and Giudicarie Faults, and 3 ) the post-20 Ma shortening across the Western Alps.

In the Southern Alps west of the Giudicarie Fault the magnitude of Neogene shortening systematically decreases from east to west (Schönborn 1992, 1999) and approaches zero along the ECORS-CROP profile near Torino (Schmid \& Kissling 2000, outside of Fig. 2). The available estimates on the magnitude of Neogene shortening in the Southern Alps east of the Giudicarie Fault are minimum estimates only (Nussbaum 2000) and hence it is unclear whether the systematic increase of shortening continues further towards east. We consider the Giudicarie Fault kinematically and temporally related to post-20 Ma shortening within the Southern Alps (Stipp et al. 2004) and therefore eliminated the later offset of the Periadriatic Fault (Schmid et al. 1999) by the Giudicarie Fault. The restoration of the Southern Alps east of the Giudicarie Fault is hence constrained by assuming an initially straight Periadriatic Fault and satisfying the minimum shortening estimates of Nussbaum (2000). Note, however, that there is no general agreement about an initially straight Periadriatic Fault (see e.g. Viola et al. 2001 for a contrasting opinion). Our palinspastic restoration (Fig. 6) reveals that the Periadriatic Fault aligns with the Balaton Fault and its eastern extension along the northern margin of the Mid-Hungarian Fault Zone (Fig. 2), a geometry that allows for the eastward lateral extrusion of the ALCAPA Mega-Unit.

The magnitude of Neogene dextral strike slip movements along the Periadriatic Fault and its eastern extension varies along strike. This is an effect of the E-W extension of the ALCAPA Mega-Unit during its lateral extrusion and displacement with respect to the Southern Alps, which were not affected by this E-W extension (Ratschbacher et al. 1991). Hence, the

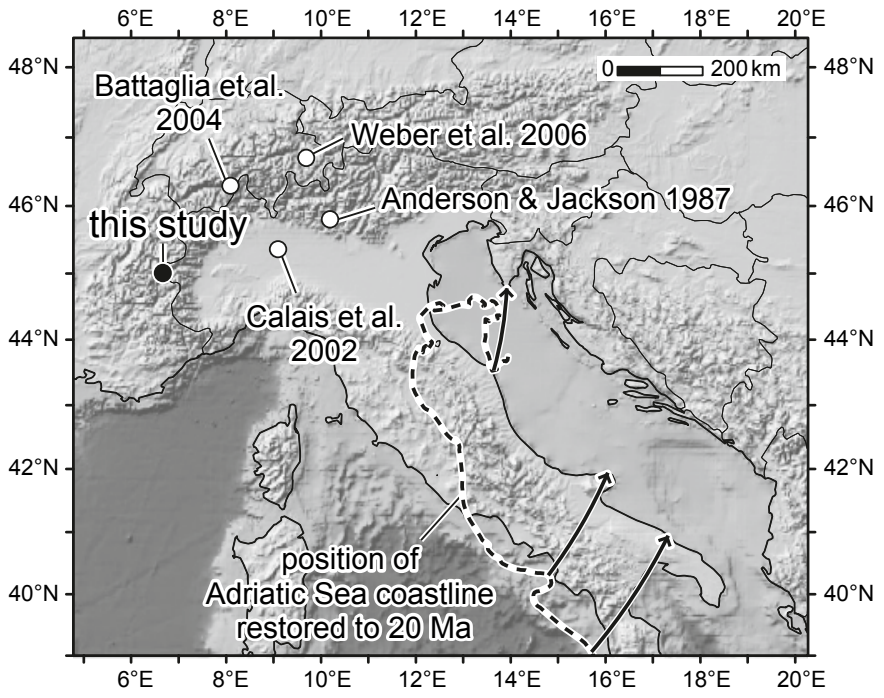

Fig. 7. Comparison of the rotation pole of the Adriatic plate indenter derived in this study (black) with previously derived poles (from the inversion of seismotectonic and/or geodetic data). The assumption of a largely rigid, rotating Adriatic plate indenter implies an increase of displacement away from the rotation pole (shown by arrows that are concentric around the rotation pole). The coastline of the Italian part of the Adriatic Sea (lying on the stable Adriatic plate) would thus be restored back to a position shown by the dashed line.

Periadriatic-Balaton Fault system represents a stretching fault in the sense of Means (1989).

In restoring the Adriatic Plate to its Early Miocene position, we took into account an extra $30 \mathrm{~km}$ of dextral displacement that is not related to extrusion of the eastern part of the Alps as a constituent of ALCAPA. This extra displacement is the result of $\mathrm{E}-\mathrm{W}$ extension across the Lepontine dome in the Central Alps, which is largely accommodated along the Simplon normal fault (just outside the western margin of Fig. 2; Grasemann \& Mancktelow 1993).

Post-20 Ma shortening across the Western Alps occurred beyond the area covered by Figs. 2 and 6, but was taken into account since it had an effect on the relative movements between the Adriatic Plate and the ALCAPA Mega-Unit. Neogene shortening across the Western Alps is relatively small, however, and varies from about $35 \mathrm{~km}$ near Geneva (e.g. Gratier et al. 1989) to less than $10 \mathrm{~km}$ further to the south in the area of the Argentera Massiv (e.g. Lickorish \& Ford 1998).

The three categories of interrelated constraints on the Neogene motion of the Adriatic Plate mentioned above jointly indicate that it underwent a combination of translation and simultaneous rotation. Once the north-directed displacement of the Adriatic Plate related to shortening in the Southern Alps has been restored to the pre- $20 \mathrm{Ma}$ situation, a $20^{\circ}$ counterclockwise rotation had to be applied to the Adriatic Plate that is described by a pivot pole located in the vicinity of Torino (at $45^{\circ} \mathrm{N}$ and $6^{\circ} 40^{\prime} \mathrm{E}$, Figs. 6 and 7). We emphasise that this rotation is a product of the above-mentioned constraints obtained from outside the Adriatic Plate. Independent estimates how- 
ever, based either on paleomagnetic data (see below), the inversion of seismotectonic (Anderson \& Jackson 1987) or GPS data (Calais et al. 2001; Battaglia et al. 2004; Weber et al. 2006) also consistently indicate a counter-clockwise rotation of the Adriatic Plate (Fig. 7).

\subsection{Restoring the tectonic units of the Dinarides}

The restoration of the major units of the Dinarides is not based on quantitative estimates of post-20 Ma shortening but is indirectly constrained by the retro-deformations applied to the Adriatic Plate and the Tisza-Dacia Mega-Unit. Within the Dinaridic-Southern Alpine domain we allowed for displacements along the following faults that were active during the past $20 \mathrm{Ma}$ : (1) South-directed thrusting in the eastward continuation of the Miocene Alpine retro-wedge (Southern Alps and their continuation into Slovenia and Hungary; Schmid et al. 2008 and references therein), (2) ongoing shortening along the frontal thrust of the Dinarides offshore Dalmatia (e.g. Bennett et al. 2008) and in line with evidence for thrusts affecting Pliocene to Quaternary sediments in the Albanian foredeep, offshore Montenegro and Albania (Picha 2002), (3) transpression along the Split-Karlovac Fault (Chorowicz 1970, 1975 and Geological Map of former Yugoslavia) and (4) thrusting along the frontal thrust of the High-Karst Unit and Budva-Cukali Zone, respectively, which override the Dalmatian Zone and its southward continuation, the Kruja Zone of Albania (Aubouin \& Ndojaj 1964) and the Gavrovo-Tripolitza Zone of Greece (Jacobshagen 1986). This thrusting affects also Mid-Miocene sediments according to new data (de Capoa et al. 1995; Mikes et al. 2008). The partitioning of displacements across the faults chosen in Fig. 6 is not constrained by hard data and will be discussed below.

The internal edge of the Tisza-Dacia Mega-Unit (internal with respect to the external one facing the Carpathian thrusts) is located adjacent to the Sava Zone, which is considered as forming the suture zone between Dinarides and Tisza-Dacia Mega-Unit (Schmid et al. 2008; Ustaszewski et al. submitted). Final closure of the Neotethyan oceanic basins along the Sava Zone had occurred in Maastrichtian to Early Paleogene times (Pamić 1993, 2002). This is constrained by the observation that Early Miocene syn-rift sediments of the Pannonian Basin system seal Mid-Eocene siliciclastics, which are affected by the last stages of post-collisional thrusting (Tari 2002; Ustaszewski et al. submitted). Consequently, the internal Dinarides are assumed to have remained attached to the TiszaDacia Mega-Unit during the last $20 \mathrm{Ma}$. Hence the position of the internal Dinarides $20 \mathrm{Ma}$ is essentially controlled by the restoration of the Tisza-Dacia Mega-Unit. Nevertheless, some minor geometrical adjustments were required across the Sava Zone (Fig. 6). These adjustments, which are relatively minor and uncontrolled by data, are thought to relate to extensional and subsequent Pliocene to recent inversion tectonics along the southern margin of the Pannonian Basin in Croatia and Serbia (Tomljenović \& Csontos 2001; Saftić et al. 2003). Dex- tral strike slip movements along the Sava Zone in Southern Serbia and Macedonia are a consequence of the restoration (see below).

\section{Discussion}

\subsection{Implications for the Southern Alps - Dinarides realm}

The Early Miocene restoration presented in Fig. 6 implies that the Neogene rotational northward motion of the Adriatic plate with respect to the stable foreland of the European plate resulted in some $190 \mathrm{~km}$ total N-S shortening in the Trieste - Eastern Alps area, at a longitude of $13^{\circ} \mathrm{E}$ to $15^{\circ} \mathrm{E}$. This shortening is partitioned between south-directed thrusting in the Southern Alps, shortening within the ALCAPA Mega-Unit and very minor $\mathrm{N}$-directed thrusting onto the northern Alpine foreland. Due to the counter-clockwise rotation of the Adriatic plate shortening in the Southern Alps decreases westward towards the rotation pivot point (Fig. 6). This decrease in shortening is compatible with estimates of Miocene $\mathrm{N}-\mathrm{S}$ shortening across the Alps of Eastern Switzerland amounting to $61 \mathrm{~km}$ during the last $19 \mathrm{Ma}$ (Schmid et al. 1996).

Conversely, the counter-clockwise rotation of the Adriatic plate indenter implies that with increasing distance E-ward away from the rotation pivot point the magnitude of shortening progressively increases (Fig. 7). In keeping with this relationship, small changes in the assumed rotation angle lead to drastic variations in the magnitude of shortening in the SE-most parts of the Dinarides, for which the deduced total shortening of $235 \mathrm{~km}$ is subject to large uncertainties. We interpret this shortening $(25+210 \mathrm{~km}$ in Fig. 6$)$ to have been predominantly taken up in the external Dinarides (offshore Dalmatia, along the SplitKarlovac Fault, along the frontal thrust of the High-Karst Unit and, further south, in front of and within the Budva-Cukali-Pindos Zone). It is very difficult to assess how this total post-20 Ma shortening in the external Dinarides is partitioned between the thrusts at the front and at the rear of the Dalmatian Zone (and its southward continuation, the Gavrovo-Tripolitza Zone). In Fig. 6 we gave preference to large amounts of shortening at the rear of the Dalmatian Zone since the amount of shortening in front of the Kruja Zone, i.e. offshore Albania appears to be relatively small (Picha 2002) while by far more substantial shortening occurred across the more internal Budva-Cukali or Krasta-Pindos Zone during the Neogene (Kilias et al. 2001). Note that Neogene to recent shortening in the Hellenides, however, occurred in a more external domain, in front of the Gavrovo-Tripolitza Zone (van Hinsbergen et al. 2005).

The deduced differential northward displacement of the Adriatic plate implies that the thrusts of the Dinarides also accommodated dextral strike-slip displacements. Substantial strike-slip faulting apparently overprinted the thrust faults of the internal Dinarides and the Sava-Vardar suture of the Sava Zone (see also Morley 1996). Dextral transpression is directly evidenced by the presently observed steep dip of these thrusts (see profile 5 of Plate 2 in Schmid et al. 2008). 


\subsection{Extension in the Pannonian Basin and contemporaneous} thrusting in the external Carpathians

Our estimate of some $290 \mathrm{~km}$ SW-NE extension in the ALCAPA Mega-Unit roughly corresponds to the minimum estimate of some $260 \mathrm{~km}$ shortening that was accommodated in the NE Carpathian thrust belt (Behrmann et al. 2000). This illustrates that Miocene thrusting and extension in these two domains are not only coeval, as proposed by Royden et al. (1983), but also of similar magnitude as shown by Behrmann et al. (2000). This supports the concept of a retreating Carpathian subduction zone, causing coeval back-arc extension. Thereby the rate of subduction is mostly or exclusively taken up by extension while the plate convergence rate, as defined by Royden \& Burchfiel (1989), approaches zero.

Comparing Figures 2 and 6 reveals that the invasion of the ALCAPA and Tisza-Dacia mega-units into the Carpathian embayment and ultimately their docking to the European foreland across the Miocene thrust belt was largely accommodated by their contemporaneous extension. Most of the significant and complex motions between these two extending mega-units took place across the Mid-Hungarian Fault Zone (Csontos \& Nagymarosy 1998). These motions were variably of a transpressional, strike slip and/or transtensional nature and were accompanied by block rotations that will be discussed in the light of paleomagnetic data below (see Tischler 2005; Tischler et al. 2007; Márton et al. 2007 for an analysis of the NE tip of the Mid-Hungarian Fault Zone).

Our restoration brings the Magura flysch belt and the Sava Zone, both forming part of the Cenozoic Alpine-Dinaridic suture zone, closely together. It also leads to a good alignment of the internal Dinarides and their two fragments, which are preserved in the Bükk and Medvednica Mountains (Tomljenović et al. 2000; Tomljenović 2000, 2002; Dimitrijević et al. 2003; Schmid et al. 2008; Tomljenović et al. 2008). The opposed subduction polarity between Alps-Western Carpathians and Dinarides demands, however, substantial post-collisional geometrical modifications of this suture (Laubscher 1971). Our model, which in many respects is similar to that of Royden \& Baldi (1988), proposes that the precursor of the present-day Mid-Hungarian Fault Zone acted as a transform fault between the opposed Alpine and Dinaridic subduction zones in Paleogene times. Since the wide area of the Carpathian embayment, depicted in Fig. 6, must have largely disappeared as a result of subduction zone retreat of the European Plate rather than by plate convergence, we speculate that this area was at least partly underlain by old, i.e. dense oceanic lithosphere rather than thick and buoyant continental lithosphere.

\subsection{Inferences from block rotations and comparison with paleomagnetic data}

Our restoration predicts counter-clockwise and clockwise rotations of the ALCAPA and Tisza-Dacia mega-units, respec- tively, during their advance into the Carpathian embayment. This is in qualitative, albeit not quantitative, agreement with the results of paleomagnetic studies on these two mega-units (e.g. Patrascu et al.1994; Márton \& Fodor 1995, 2003; Márton \& Márton 1996; Panaiotu 1998, 1999; Márton 2000). In general our restoration predicts smaller rotations than those inferred from paleomagnetic data. This can partly be explained by the fact that the two extending mega-units do not represent rigid blocks, and that smaller blocks forming perhaps part of larger scale fault zones may be subjected to more intense rotations. On the other hand, the timing of magnetization, and hence the timing of these rotations cannot always be determined accurately. In the case of the Tisza-Dacia Mega-Unit Fügenschuh \& Schmid (2005) argued, based on purely geological-tectonic arguments, that much of a total of $90^{\circ}$ clockwise rotation, generally reported to be entirely of Miocene age (e.g. Patrascu et al. 1994), pre-dates the Miocene.

In the case of the counter-clockwise rotation of the ALCAPA Mega-Unit we interpret this rotation to result from the combined effect of slab retreat and its collision with the simultaneously advancing Tisza-Dacia Mega-Unit (e.g. Tischler et al. 2007). However, we regard the clockwise rotation of the Tisza-Dacia Mega-Unit to be driven by slab retreat only; it was accommodated by dextral displacements along the Timok and Cerna-Jiu Faults (Fügenschuh \& Schmid 2005).

Concerning the counter-clockwise rotation of the Adriatic Plate and the external Dinarides we again obtain a smaller amount of rotation $\left(20^{\circ}\right)$ from our reconstruction compared to the $30^{\circ}$ inferred from paleomagnetic data for latest Miocene to recent times (Márton et al. 2003). It is evident that rotations larger than those predicted by our restoration would not only be inconsistent with the data we used as input for our restoration but also would lead to massive overestimates of shortening in the southern Dinarides, located far from the pole of rotation.

The clockwise rotations of up to $100^{\circ}$ recorded on fragments of the internal Dinarides exposed in the Medvednica Mountains are interpreted as being restricted to small blocks (Tomljenović 2002; Tomljenović et al. 2008) rather than applying to the Dinarides as a whole. The $53^{\circ}$ counterclockwise rotation, which we applied in our reconstruction to another fragment of the internal Dinarides, the Bükk Mountains, was arrived at by leaving this fragment attached to the ALCAPA Mega-Unit and by straightening out the Periadriatic-Balaton-Darno Faults. This qualitatively agrees also well with paleomagnetic data from the Bükk Mountains reporting counter-clockwise rotations between 30 and $80^{\circ}$ (Márton \& Fodor 1995), as well as tectonic and paleogeographic data (Csontos 1999, 2000). The $16.5^{\circ}$ clockwise rotation indicated in Fig. 6 for the southernmost part of the TiszaDacia Mega-Unit is, on the other hand, a mere consequence of our restoration and is not supported by paleomagnetic data. 

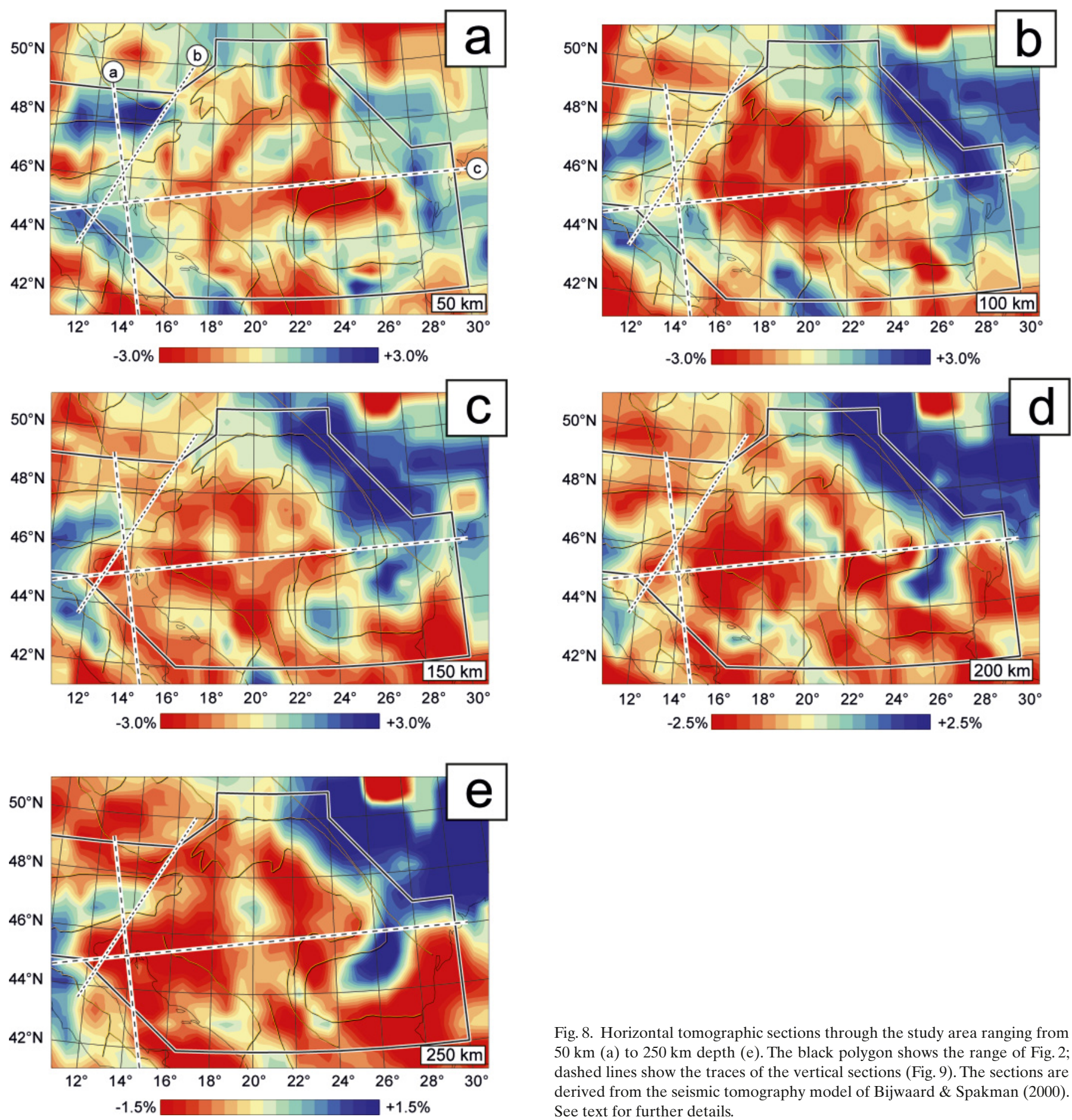

Fig. 8. Horizontal tomographic sections through the study area ranging from $50 \mathrm{~km}$ (a) to $250 \mathrm{~km}$ depth (e). The black polygon shows the range of Fig. 2; dashed lines show the traces of the vertical sections (Fig. 9). The sections are derived from the seismic tomography model of Bijwaard \& Spakman (2000). See text for further details.

\subsection{Implications regarding the present-day lithosphere-scale configuration}

Our reconstruction has bearings on the interpretation of the present-day lithospheric configuration of the Alpine-Carpathian-Dinaridic orogenic system (Figs. 8 \& 9). In particular, it potentially provides an explanation for the change in the

lithosphere-scale configuration that is observed in the Eastern Alps according to recent results of high-resolution teleseismic mantle tomography (Lippitsch et al. 2003; Schmid et al.2004a,b; Kissling et al. 2006). This work demonstrated the existence of a NNE-dipping lithospheric slab ("Adriatic slab") underneath the Eastern Alps in the area east of the Giudicarie Fault (Fig. 9b; Lippitsch et al. 2003), while another slab ("European slab") 
preserved west of this fault dips to the SE (Kissling et al. 2006), as is expected for the European lithosphere which represents the southwards subducted lower plate during Alpine collision. The consistent overall architecture of the crustal configuration during Alpine collision, unchanged all the way into the Western Carpathians (Schmid et al. 2008), implies that the European lithosphere formerly represented the lower plate also in the area east of the Giudicarie Fault; this in turn suggests that a late-stage post-collisional modification of the lithosphere-scale geometry must have occurred in the easternmost Alps. In a first step we discuss the time constraints for the onset of this change in subduction polarity, and in a second step we suggest possible mechanisms, which could have led to this severe modification.

The length of the subducted "Adriatic slab" east of the Giudicarie Fault was estimated to about $210 \mathrm{~km}$ along a NE-SW section (Fig. 9b; Lippitsch et al. 2003) across the Eastern Alps. Within error this value is perfectly compatible with our estimate of a total of $190 \mathrm{~km} \mathrm{~N}$-S-shortening (Fig. 6) inferred for a N-S transect through the Trieste - Eastern Alps area, which intersects the tomography section $\mathrm{C}^{-\mathrm{C}^{\prime}}$ of Lippitsch et al. (2003; see Fig. 9b). This strongly suggests that the NE-directed subduction of the Adriatic lithosphere was associated with post-20 Ma crustal shortening. The average plate convergence rate would be in the order of $1 \mathrm{~cm} \mathrm{yr}^{-1}$ for the last $20 \mathrm{Ma}$ across the Eastern and Southern Alps along the transect depicted in Fig. 9b. According to our palinspastic restoration (Fig. 6) the post-20 Ma plate convergence rate decreases westwards, which agrees with the plate convergence rate estimates between 0.3 and $0.5 \mathrm{~cm} \mathrm{yr}^{-1}$ derived from an Alpine transect through Eastern Switzerland and based on geological estimates (Schmid et al. 1996). Note that present-day convergence rates between the western parts of the Adriatic plate are also smaller, i.e. in the order of $0.5 \mathrm{~cm} \mathrm{yr}^{-1}$ (Battaglia et al. 2004).

Based on literature data and the results of our restoration we propose that a dramatic change has occurred at about $20 \mathrm{Ma}$, when the S to SE-wards subducting European Plate gave way to the NE-wards subducting Adriatic Plate below the Alps east of the Giudicarie Fault. Comparison of Figs. 2 and 6 reveals that the change in subduction polarity in the easternmost Alps was associated with substantial strike slip displacements and hence cannot be understood without considering the entire AlpineCarpathian-Dinaridic system in three dimensions.

In order to analyse the geometry of the mantle lithospheric configuration east of the Giudicarie Fault in more detail, we present five horizontal tomographic slices (Fig. 8) that were derived from the seismic tomography model of Bijwaard \& Spakman (2000). Inconsistencies between these sections and those presented in the area of the Eastern Alps are primarily due
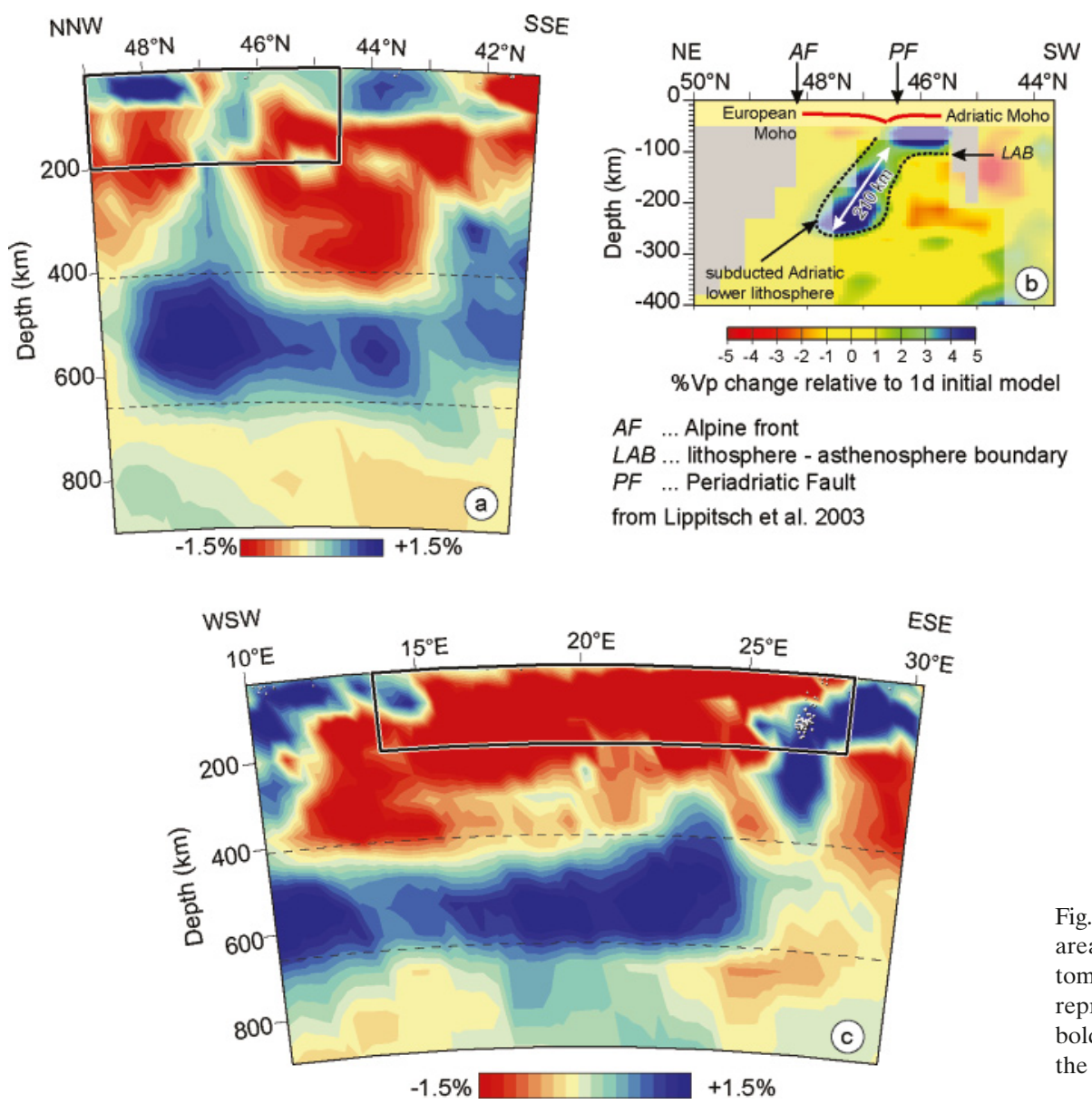

Fig. 9. Vertical tomographic sections through the study area. (a) and (c) are sections derived from the seismic tomography model of Bijwaard \& Spakman (2000), (b) represents section $\mathrm{C}-\mathrm{C}^{\prime}$ of Lippitsch et al. (2003). The bold black rectangles in (a) and (c) show the extent of the vertical walls of the block diagram of Fig. 11. 
to the higher resolution achieved by Lippitsch et al. (2003) in the Alpine region, who applied corrections for lateral velocity changes in the crust. The sections show the following first-order characteristics that can also be seen in the horizontal sections of Piromallo \& Morelli (2003, their Fig. 8): (1) High $V_{p}$ anomalies in the sections at 50 and $100 \mathrm{~km}$ depth (Figs. 8a \& b) suggest a continuous Adriatic lithosphere between the Eastern Alps and the Dinarides. At depths greater than $100 \mathrm{~km}$, high $\mathrm{V}_{\mathrm{p}}$ anomalies underneath the Dinarides are confined to latitudes south of $44^{\circ} \mathrm{N}$, but are absent further north (Fig. 8c-e). This suggests that an Adriatic lithosphere slab dipping underneath the Dinarides is only present south of $44^{\circ} \mathrm{N}$ and that a connection to the slab underneath the Eastern Alps identified by Lippitsch et al. (2003) cannot be inferred from the data available. (2) The area of high $\mathrm{V}_{\mathrm{p}}$ below the northernmost Eastern Alps (north of latitude $47^{\circ}$ in Fig. 8a) is part of the European lithosphere, which also surrounds the Eastern Carpathians based on geological arguments. Note that the immediate connection of high velocity mantle underneath the Eastern Alps to the circumCarpathian European lithosphere is not obvious from Fig. 8. Further east, however, the European lithosphere is again well depicted by fast velocities in Figs. $8 \mathrm{~b}$ to e, and connects southeastwards with the sub-vertically oriented Vrancea slab north of Bucharest that is a part of Moesia (Matenco et al. 2007). (3) Low velocities characterise the area of the Pannonian Basin. The area of high velocities underneath the Eastern Alps depicted in the horizontal sections of Fig. 8 cannot unequivocally be attributed to either the Adriatic slab identified by Lippitsch et al. (2003) nor, alternatively, to a remnant of the former Sward subducting European slab that must have retreated or broken off at $20 \mathrm{Ma}$, giving way to the Adriatic slab.

In order to further investigate this matter we looked at three vertical tomographic sections (Fig. 9). Fig. 9a clearly shows a horizontal high velocity body located at the northernmost rim of the Alps north of about $47^{\circ}$ latitude and extending into the Bohemian massif (see also Fig. 8a). The lower interface of this body extends down to a depth of less than $100 \mathrm{~km}$. Because of its location, this high velocity body clearly has to be correlated with the European lithosphere. The downward tapering low velocity anomaly at $47^{\circ} \mathrm{N}$ coincides with the topographically highest part of the Eastern Alps along this transect and very likely represents a deep crustal root underneath the Eastern Alps (see Kissling \& Spakman 1996). The high velocities south of $47^{\circ} \mathrm{N}$ represent Adriatic lithosphere that dips steeply northward underneath the European lithosphere. The exact length of this slab cannot be estimated from Fig. 9a due to "blurring" (upward conical high velocity anomalies that are likely caused by the incident angles of the ray paths used in the tomography).

The section in Fig. 9b represents the high-resolution tomographic section of Lippitsch et al. (2003) and is shown at exactly the same scale as the section in Fig. 9a. The Adriatic slab is clearly shown to be dipping underneath the Eastern Alps reaching a depth of c. $270 \mathrm{~km}$. In combination, the sections Fig. 9a and 9b clearly suggest that Adriatic lithosphere is dipping underneath the European lithosphere. The section in Fig. 9c shows that the high velocity body representing the Adriatic lithosphere at the western end of the section does not continue further to the east beyond $15^{\circ} \mathrm{E}$ (longitude of Zagreb), neither horizontally nor as a dipping slab. The Pannonian Basin is characterised by low velocities throughout, suggesting a very reduced lithosphere thickness there. However, assuming that an average stretching factor $\delta$ around 1.6 (see section 2.3) also affected the mantle lithosphere, initial total lithosphere thickness being c. $100 \mathrm{~km}$, one would still expect a lithosphere thickness of roughly $60 \mathrm{~km}$ from tectonic stretching alone, i.e. much more than observed in Fig. 9c. This discrepancy confirms the widely accepted view first proposed by Sclater et al. (1980) that the lithosphere underneath the Pannonian Basin has been, in addition to tectonic stretching, substantially thermally attenuated. This is also in line with the widespread occurrence of Late Miocene to Pleistocene alkalic and mafic magmatics with an inferred asthenospheric source, postdating subduction-related magmatism in the area (e.g. Wilson \& Downes 2006).

The horizontal depth slices at $100 \mathrm{~km}$ depth by Lippitsch et al. (2003, their Fig. 12a), Piromallo \& Morelli (2003, their Fig. 8) and our Fig. $8 \mathrm{~b}$ were used for mapping the location of the upper mantle-lithosphere boundary of the NE-ward subducted Adriatic slab underneath the Eastern Alps and internal Dinarides, or the eastern limit of the Adriatic lithosphere where no slab can be discerned dipping underneath the Dinarides. We did this by contouring the transition from positive to negative $V_{p}$ variations along the presumed NE edge of the Adriatic lithosphere as it intersects these three horizontal sections. We are fully aware that the $0 \% \mathrm{~V}_{\mathrm{p}}$ variation contours in the horizontal sections are not comparable, since they strongly depend on the $\mathrm{V}_{\mathrm{p}}$ mantle velocity models used by the different authors as well as on the accuracy of these models. Nevertheless we plotted these contours onto the tectonic map of Fig. 2 for a qualitative assessment (Fig. 10). In combination with Figs. 8 and 9, the contours in Fig. 10 suggest the following: (1) The Adriatic lithosphere can be traced continuously from the Eastern Alps into the Dinarides. (2) However, a lithospheric slab can only be confidently identified in the high-resolution area of Lippitsch et al. (2003) and south of $44^{\circ} \mathrm{N}$ (roughly the latitude of Sarajevo) in the Dinarides, but is absent according to the tomographic data available in the area between. Given the currently available tomographic models, the southeastern limit of the Adriatic slab identified by Lippitsch et al. (2003) is speculative. Horváth et al. (2006) suggested its south-eastern termination along the Zagreb Line (corresponding to the western part of the Mid-Hungarian Fault Zone, Fig. 2). This problem should be addressed by future geophysical studies. Interestingly, the area where no Adriatic slab can be seen in the tomographic models coincides with the location of the western rim of the Pannonian Basin in parts of the Dinarides, a basin that has experienced substantial tectonic stretching and asthenospheric uprising. It is therefore conceivable that asthenospheric upwelling underneath the Pannonian Basin led to a severe modification of a formerly continuous Adriatic lithospheric slab dipping underneath the Dinarides,

S288 K. Ustaszewski et al. 


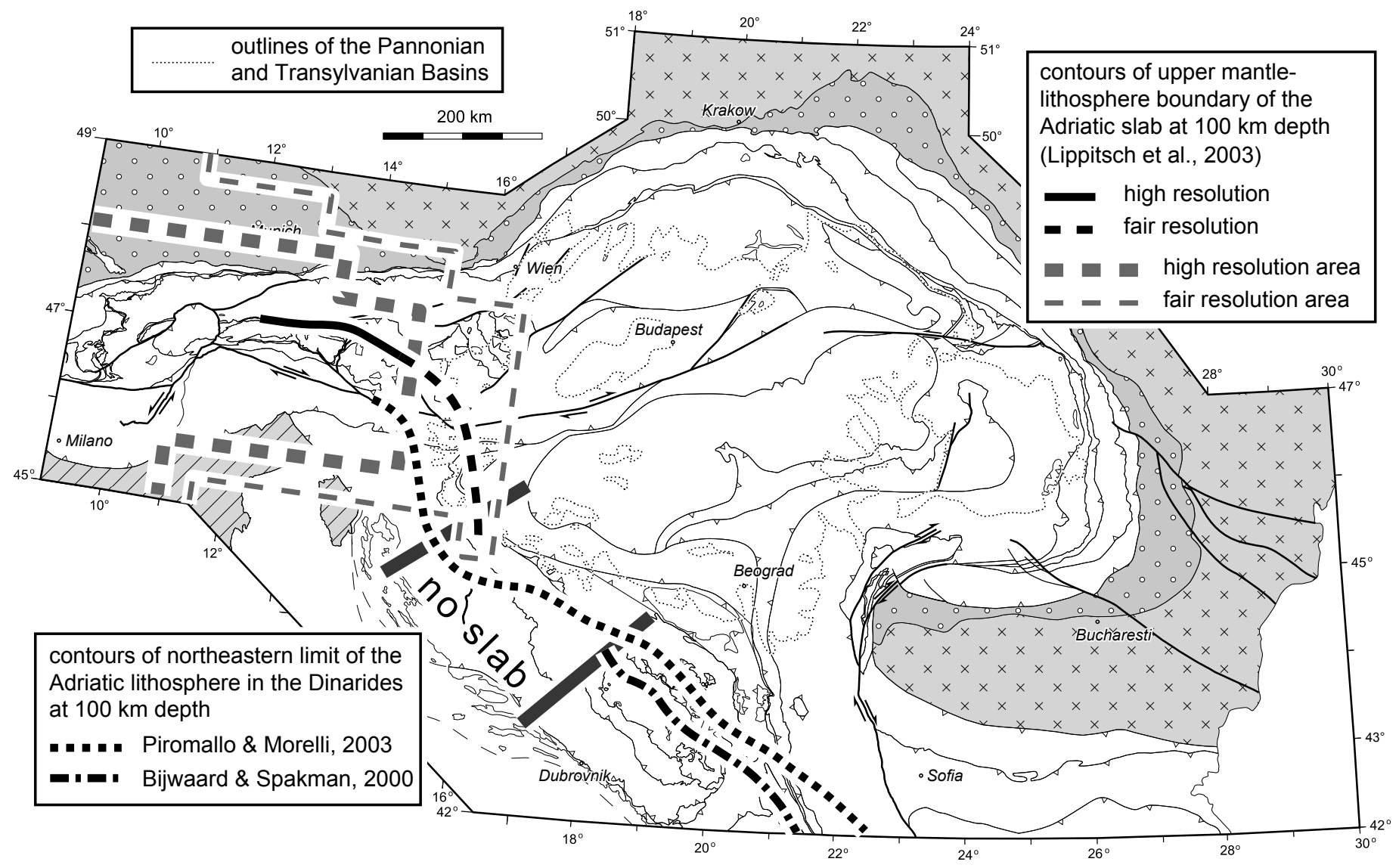

Fig. 10. Contours of the upper mantle-lithosphere boundary of the Adriatic slab at $100 \mathrm{~km}$ depth as inferred from the $3 \mathrm{D} \mathrm{V} \mathrm{V}_{\mathrm{p}}$-model of Lippitsch et al. (2003, their Fig. 12) in comparison with the contours of the eastern limit of the Adriatic lithosphere underneath the Dinarides using the horizontal depth slices at $100 \mathrm{~km}$ depth of Piromallo \& Morelli (2003, their Fig. 8) and Bijwaard \& Spakman (2000; our Fig. 8b). The contours were derived by tracing the transition from positive to negative $\mathrm{V}_{\mathrm{p}}$ variations of each model along the presumed NE edge of the Adriatic lithosphere. The contours are superimposed onto the outlines of the tectonic units of Fig. 2. See text for further details.

just as it caused strong thermal attenuation of the lithosphere underneath the Pannonian Basin itself, creating pathways for asthenosphere-derived melts.

Fig. 11 presents a 3D sketch, which integrates the presentday crustal structure of the Alpine-Carpathian-Dinaridic system (Schmid et al. 2008) with the present-day lithosphere-scale configuration inferred from the results of mantle tomography discussed above. This sketch allows for a brief discussion of the mechanisms, which could have led to changes of the original lithospheric configuration that induced the severe post-20 Ma crustal displacements, rotations and deformations that are evident from comparing Figures 2 and 6.

Clearly, the post-20 Ma emplacement of a once continuous Adriatic slab underneath the Eastern Alps was only possible once the European slab underneath the Eastern Alps gave way by slab break-off, a process that initiated earlier, i.e. between 40 and $35 \mathrm{Ma}$, in the transition area between Western and Eastern Alps (von Blanckenburg \& Davis 1995) but took place at around $20 \mathrm{Ma}$ in the Eastern Alps and the area of the Carpathian embayment. Whether or not this break-off was a continuous process, systematically migrating eastward (Spakman \& Wortel
2000), is not yet fully understood. The Carpathian embayment was formerly underlain, according to most authors (e.g. Balla 1982; Mason et al. 1998), at least partly by oceanic lithosphere. Subduction and slab retreat (e.g. Royden 1988; Wortel \& Spakman 2000; Sperner et al.2002,2005), starting at around 20 Ma in the area of the Carpathian embayment, created the necessary space that allowed for the invasion of the ALCAPA, Tisza and Dacia mega-units and the formation of the highly arcuate Alpine-Carpathian orogenic system. However this retreat, associated with severe crustal thinning and upwelling of the asthenosphere underneath the Pannonian Basin, cannot be the only driving force for this substantial post-20 Ma reorganization.

Rotation and north-directed translation of the Adriatic Plate indenter, also including the underpinnings of the adjacent Dinaridic orogen, provided a second and probably equally important driving force for these modifications. The displacement of the Adriatic Plate, of course in combination with slab break off or retreat of the European Plate, led to the change in subduction polarity along the transect through the easternmost Alps depicted in Fig. 11. Due to the simultaneous counterclockwise rotation of the Adriatic Plate indenter, its effects in 


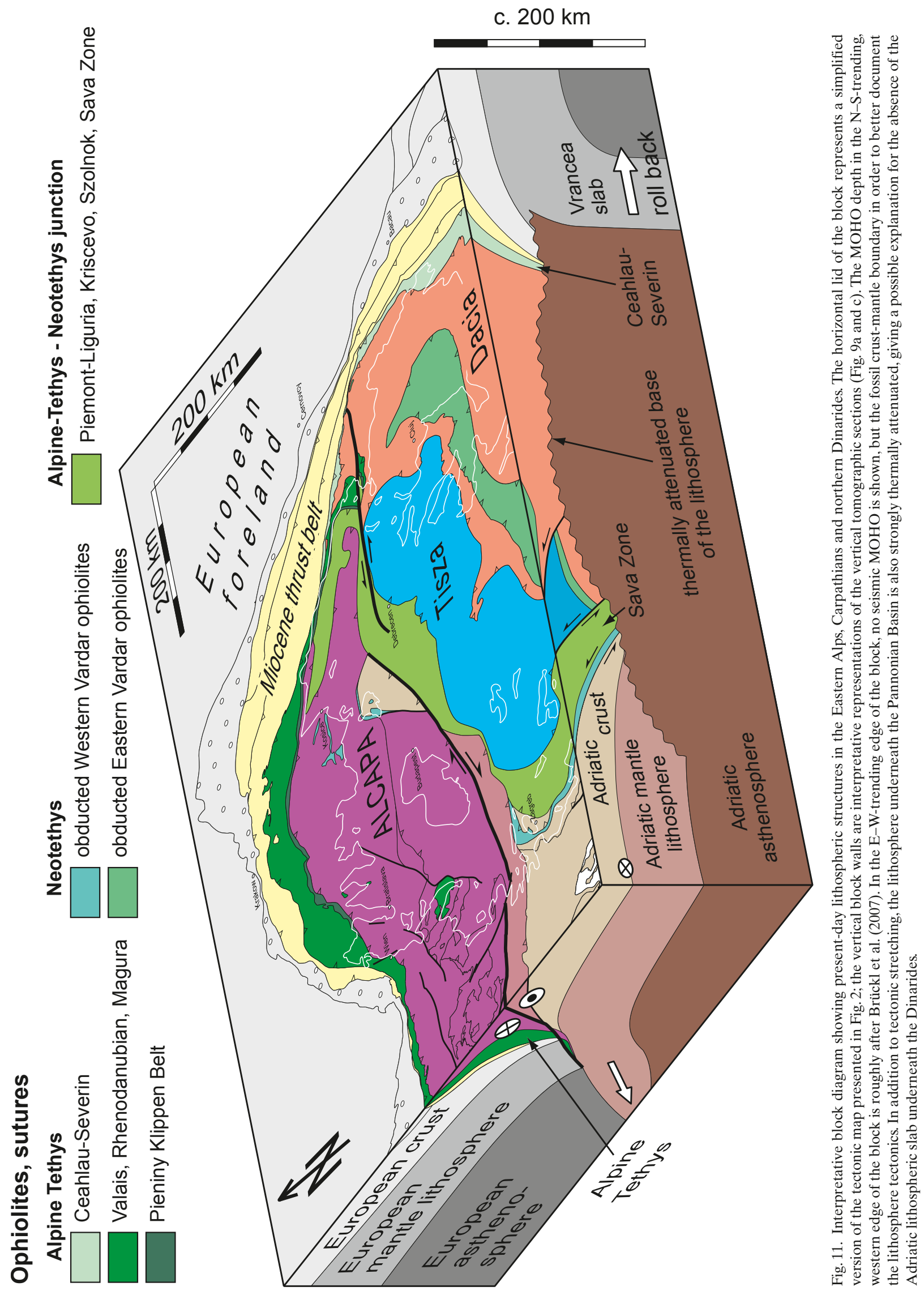


terms of post-20 Ma shortening are relatively minor in the Western Alps, but become increasingly important eastwards (N-S transect corresponding to the western edge of the block model in Fig. 11). After the Latest Miocene to Pliocene, i.e. the onset of intra-plate folding and overall Quaternary inversion (e.g. Matenco et al. 2006; Cloetingh et al. 2007) compression due to the Adria push also largely governed the easternmost parts of the Alpine-Carpathian-Dinaridic system of orogens.

\section{Conclusions}

We conclude that:

1) The Mid-Hungarian Fault Zone was the locus of a Paleogene plate boundary transforming opposed subduction polarities between Alps (including Western Carpathians) and Dinarides before $20 \mathrm{Ma}$ ago.

2) The ALCAPA Mega-Unit fitted into an area $W$ of present-day Budapest, while the Tisza-Dacia Mega-Unit was already on its way invading the Carpathian embayment.

3) That slab retreat of the partly oceanic European lithosphere provided an important driving force for extension and compression in the Pannonian-Carpathian realm considered as a closed system associated with negligible plate convergence. However, we conclude that the rotating Adriatic Plate indenter provides an additional important driving force, interfering with slab retreat but primarily responsible for:

4) Neogene shortening amounts to over $200 \mathrm{~km}$ across the southern external Dinarides, contemporaneous with dextral wrench movements in the Dinarides and the adjacent Carpatho-Balkan orogen, and:

5) $\mathrm{N}-\mathrm{S}$ convergence between the European and Adriatic plates and amounts to some $200 \mathrm{~km}$ at a longitude of $14^{\circ} \mathrm{E}$ is in line with post-20 Ma emplacement of a formerly possibly continuous Adriatic slab underneath the Eastern Alps, corroborating the interpretation of results based on highresolution teleseismic tomography.

\section{Acknowledgements}

We acknowledge financial support through the Swiss National Science Foundation (projects "Tisza" Nrs. 200021-101883/1 and 200020-109278/1). We thank Liviu Matenco (Amsterdam) and Peter Ziegler (Basel) for critical remarks on an earlier version of the manuscript. We further acknowledge the very thorough and constructive reviews of Ewald Brueckl (Vienna), Niko Froitzheim (Bonn) and Philippe Agard (Paris).

\section{REFERENCES}

Anderson, H. \& Jackson, J. 1987: Active tectonics of the Adriatic Region. Geophysical Journal of the Royal Astronomical Society 91, 937-983.

Aubouin, J. \& Ndojaj, I. 1964: Regards sur la géologie de l'Albanie et sa place dans la géologie des Dinarides. Bulletin de la Société Géologique de France 7/6, 593-625.

Balla,Z.1987:Tertiary paleomagnetic data for the Carpatho-Pannonian region in the light of Miocene rotation kinematics. Tectonophysics 139, 67-98.
Battaglia, M., Murray, M.H., Serpelloni, E. \& R., B. 2004: The Adriatic region: An independent microplate within the Africa-Eurasia collision zone. Geophysical Research Letters 31, L09605, doi:10.1029/2004GL019723.

Behrmann, J.H., Stiasny, S., Milicka, J. \& Pereszlenyi, M. 2000: Quantitative reconstruction of orogenic convergence in the northeast Carpathians. Tectonophysics 319,111-127.

Bennett, R.A., Hreinsdóttir, S., Buble, G., Bašic, T., Marjanović, M., Casale, G., Gendaszek, A. \& Cowan, D., 2008. Eocene to present subduction of southen Adria mantle lithosphere beneath the Dinarides. Geology 36, 3-6.

Bérczi, I., Hámor, G., Jámbor, Á. \& Szentgyörgyi, K. 1988: Neogene sedimentation in Hungary. In: Royden, L.H. \& Horváth, F. (Eds.): The Pannonian Basin. A Study in Basin evolution, AAPG Memoir 45. The American Association of Petroleum Geologists and the Hungarian Geological Society, Budapest, Hungary, 57-67.

Berza, T. \& Drăgănescu, A. 1988: The Cerna-Jiu fault system (South Carpathians, Romania), a major Tertiary transcurrent lineament. Dări de Seamă Institutul de Geologie si Geofizică 72-73, 43-57.

Berza, T. \& Iancu, V. 1994: Variscan events in the basement of the Danubian nappes (South Carpathians). ALCAPA II Field Guidebook. Romanian Journal of Tectonics and Regional Geology 75, 93-104.

Bijwaard, H \& Spakman W. 2000: Non-linear global P-wave tomography by iterated linearized inversion. Geophysical Journal International 141, 71-82.

Brückl, E., Bleibinhaus, F., Gosar, A., Grad, M., Guterch, A., Hrubcová, P., Keller, R., Majdański, M., Šumanovac, F., Tiira, T., Yliniemi, J., Hegedűs, E. \& Thybo, H. 2007: Crustal structure due to collisional and escape tectonics in the Eastern Alps region based on profiles Alp01 and Alp02 from the ALP 2002 seismic experiment. Journal of Geophysical Research 112, B06308, doi:10.1029/2006JB004687.

Burchfiel, B.C., 1980. Eastern European Alpine system and the Carpathian orocline as an example of collision tectonics. Tectonophysics 63,31-61.

Burkhard, M. \& Sommaruga, A. 1998: Evolution of the western Swiss Molasse basin: Structural relations with the Alps and the Jura belt. In Mascle C. et al. (Eds.): Cenozoic Foreland Basins of Western Europe. Geological Society Special Publications 134, 279-298.

Calais, E., Nocquet, J.-M., Jouanne, F. \& Tardy, M. 2001: Current strain regime in the Western Alps from continuous Global Positioning System measurements, 1996-2001. Geology 30, 651-654.

Cavazza, W., Roure, F., Spakman, W., Stampfli, G.M. \& Ziegler, P. (Editors), 2004: The TRANSMED Atlas. The Mediterranean Region from Crust to Mantle. Springer, Berlin, Heidelberg, New York, 141 pp. + CD-ROM.

Channel, J.E.T. \& Horváth, F. 1976: The African/Adriatic promontory as a paleogeographical premise for Alpine orogeny and plate movements in the Carpatho-Balkan region. Tectonophysics 35, 71-101.

Chorowicz, J. 1970: La transversale de Zrmanja (Yougoslavie). Bulletin de la Société Géologique de France 12/6, 1028-1033.

Chorowicz, J. 1975: Mechanics of Split-Karlovac transversal structure in Yugoslavian Dinarides. Compte-Rendu Académie des Sciences Série D 280/20, 2313-2316.

Cloetingh, S., Bada, G., Matenco, L., Lankreijer, A., Horvath, F. \& Dinu, C. 2006: Modes of basin (de)formation, lithospheric strength and vertical motions in the Pannonian-Carpathian system: inferences from thermomechanical modelling. In: Gee, D.G. \& Stephenson, R.A. (Eds.): European Lithosphere Dynamics, Geological Society London Memoirs 32, 207-221.

Csontos, L. 1995:Tertiary tectonic evolution of the Intra-Carpathian area: a review. In: Downes, H. \& Vaselli, O. (Eds.): Neogene and related magmatism in the Carpatho-Pannonian region). Acta Vulcanologica 7, 1-13.

Csontos, L. 1999: Structural outline of the Bükk Mts. (N Hungary). Text in Hungarian, abstract and figure captions translated. Földtani Kölöny 129 611-651.

Csontos, L. 2000: Stratigraphic re-evaluation of the Bükk Mts (N Hungary). Text in Hungarian, abstract and figure captions translated. Földtani Kölöny 130, 95-131.

Csontos, L., Nagymarosy, A., Horvath, F. and Kováč, M., 1992. Tertiary evolution of the Intra-Carpathian area: A model. Tectonophysics 208(1-3): 221-241.

Csontos, L. \& Nagymarosy, A. 1998: The Mid-Hungarian line: a zone of repeated tectonic inversions. Tectonophysics $297,51-71$. 
Csontos, L. \& Vörös, A. 2004: Mesozoic plate tectonic reconstruction of the Carpathian region. Palaeogeography, Palaeoclimatology, Palaeoecology 210,1-56.

de Capoa, P., Radoicic, R. \& D’Argenio, B., 1995. Late Miocene deformation of the External Dinarides (Montenegro and Dalmatia). New biostratigraphic evidence. Memorie di Scienze Geologiche 47, 157-172.

Dewey, J.F., Pitman III, W.C., Ryan, W.B. F. \& Bonnin, J. 1973: Plate tectonics and the evolution of the Alpine system. Geological Society of America Bulletin 84, 3137-3180.

Dimitrijević, M.N., Dimitrijević, M.D., Karamata, S., Sudar, M., Gerzina, N., Kovács, S., Dostály, L., Gulácsi, Z., Less, G. \& Pelikán, P. 2003: Olistostrome/mélanges - an overview of the problems and preliminary comparison of such formations in Yugoslavia and NE Hungary. Slovak Geological Magazine 9, 3-21.

Ellouz, N. \& Roca, E. 1994: Palinspastic reconstructions of the Carpathians and adjacent areas since the Cretaceous: a quantitative approach. In: Roure, F. (Ed.): Peri-Tethyan Platforms. Édition Technip, Paris, 51-78.

Fodor, L., Jelen, B., Márton, E., Skaberne, D., Car, J. \& Vrabec, M. 1998: Miocene-Pliocene tectonic evolution of the Slovenian Periadriatic fault: Implications for Alpine-Carpathian extrusion models. Tectonics 17, 690-709.

Fodor, L., Csontos, L., Bada, G., Györfi, I. \& Benkovics, L. 1999: Tertiary tectonic evolution of the Pannonian Basin system and neighbouring orogens: a new synthesis of palaeostress data. In: Durand, B., Jolivet, L., Horvath, F. \& Séranne, M. (Eds.): The Mediterranean Basins: Tertiary Extension within the Alpine Orogen. Geological Society London Special Publications 156, 295-334.

Frisch, W., Kuhlemann, J., Dunkl, I. \& Brügel, A. 1998: Palinspastic reconstruction and topographic evolution of the Eastern Alps during late Tertiary tectonic extrusion. Tectonophysics 297, 1-15.

Froitzheim, N., Conti, P. \& van Daalen, M. 1997: Late Cretaceous, synorogenic, low-angle normal faulting along the Schlinig fault (Switzerland, Italy, Austria) and its significance for the tectonics of the Eastern Alps. Tectonophysics 280, 267-293.

Fügenschuh, B., Seward, D. \& Mancktelow, N.S. 1997: Exhumation in a convergent orogen: the western Tauern window. Terra Nova 9, 213-217.

Fügenschuh, B. \& Schmid, S.M., 2005. Age and significance of core complex formation in a very curved orogen: Evidence from fission track studies in the South Carpathians (Romania). Tectonophysics 404, 33-53.

Genser, J. \& Neubauer, F. 1989: Low angle normal faults at the eastern margin of the Tauern window (Eastern Alps). Mitteilungen der Österreichischen Geologischen Gesellschaft 81, 233-243.

Gradstein, F., Ogg, J. \& Smith, A.G. 2004: A Geologic Time Scale. Cambridge University Press, Cambridge, $589 \mathrm{pp}$.

Grasemann, B. \& Mancktelow, N.S. 1993: Two-dimensional thermal modelling of normal faulting: the Simplon Fault Zone, Central Alps, Switzerland. Tectonophysics $225,155-165$.

Gratier, J.-P., Ménard, G. \& Arpin, R. 1989. Strain-displacement compatibility and restoration of the Chaînes Subalpines of the Western Alps. In: Coward, M.P., Dietrich, D. \& Park, R.G. (Eds.): Alpine Tectonics, Geological Society Special Publication 45, 65-81.

Haas, J. 2001: Geology of Hungary. Eötvös University Press, Budapest, $317 \mathrm{pp}$.

Haas, J. \& Pero, C. 2004: Mesozoic evolution of the Tisza Mega-unit. International Journal of Earth Sciences 93, 297-313.

Harangi, S., Downes, H. \& Seghedi, I. 2006: Tertiary-Quaternary subduction processes and related magmatism in the Alpine-Mediterranean region. In: Gee, D.G. \& Stephenson, R. (Eds.): European Lithosphere Dynamics. Geological Society of London Memoir 32,167-190.

Horváth, F., 1993. Towards a mechanical model for the formation of the Pannonian basin. Tectonophysics 226(1-4), 333-357.

Horváth, F. \& Royden, L.H. 1981: Mechanism for formation of the intra-Carpathian basins: a review. Earth Evolution Sciences 1,307-316.

Horváth, F. \& Tari, G.C. 1999: IBS Pannonian Basin project; a review of the main results and their bearings on hydrocarbon exploration. In: Durand, B., Jolivet, L., Horváth, F. \& Seranne, M. (Eds.): The Mediterranean basins; Tertiary extension within the Alpine Orogen. Geological Society London Special Publications 156, 195-213.
Horváth, F., Bada, G., Szafián, P., Tari, G., Ádám, A. \& Cloetingh, S. 2006: Formation and deformation of the Pannonian Basin: constraints from observational data. In: Gee, D.G. \& Stephenson, R. (Eds.): European Lithosphere dynamics, Geological Society London Memoir 32, 191-206.

Hrvatović, H. 2000: Post-Orogenic Intramontane Basins. In: Pamić, J. \& Tomljenović, B. (Eds.): PANCARDI 2000. Field trip guide book, Dubrovnik. Vijesti Hrvatskoga Geoloskog Drustva 37, 73-74.

Jacobshagen, V. 1986: Geologie von Griechenland. Beiträge zur regionalen Geologie der Erde, 19. Gebrüder Bornträger, Berlin, 363 pp.

Jiříček, R. 1979: Tektogeneticky vyvoj karpatskeho oblouku behem oligocenu a neogenu (in Czech, translated title: Tectogenetic development of the Carpathian Arc in the Oligocene and Neogene). In: Machel, M. (Ed.):Tectonic profiles through the West Carpathians. Geol. Ustav Dionyza Stura, Bratislava, 203-214.

Krézsek, C., Bally, A.W. 2006: The Transylvanian Basin (Romania) and its relation to the Carpathian fold and thrust belt: insight in gravitational salt tectonics. Marine and Petroleum Geology 23, 405-442.

Kilias, A., Tranos, M., Mountrakis, D., Shallo, M., Marto, A. \& Turku, I. 2001 : Geometry and kinematics of deformation in the Albanian orogenic belt during the Tertiary. Journal of Geodynamics 31, 169-187.

Kissling, E. \& Spakman, W. 1996: Interpretation of tomographic images of uppermost mantle structure: examples from the Western and Central Alps. Journal of Geodynamics 21, 97-111.

Kissling, E., Schmid, S.M., Lippitsch, R., Ansorge, J. \& Fügenschuh, B. 2006: Lithosphere structure and tectonic evolution of the Alpine arc: new evidence from high-resolution teleseismic tomography. In: Gee, D.G. \& Stephenson, R.A. (Eds.): European Lithosphere Dynamics, Geological Society London Memoirs 32,129-145.

Kováč, M., Nagyymarosy, A., Oszczypko, N., Csontos, L., Slączka, A., Maruntieanu, M., Matenco, L. \& Márton, E. 1998: Palinspastic reconstruction of the Carpathian-Pannonian region during the Miocene. In: Rakus, M. (Ed.): Geodynamic development of the Western Carpathians. Geological Survey of the Slovak Republic, Bratislava, 189-217.

Kovács, I., Csontos, L., Szabó, C., Bali, E., Falus, G., Benedek, K. \& Zajacz, Z. 2007: Paleogene-early Miocene igneous rocks and geodynamics of the Alpine-Carpathian-Pannonian-Dinaric region: An integrated approach. In: Beccaluva, L., Bianchini, G. \& Wilson, M. (Eds.): Cenozoic volcanism in the Mediterranean Area, Geological Society of America Special Paper 418, 93-112.

Kounov, A., Seward, D., Bernoulli, D., Burg, J.-P. \& Ivanov, Z. 2004: Thermotectonic evolution of an extensional dome: the Cenozoic Osogovo-Lisets core complex (Kraishte zone, western Bulgaria). International Journal of Earth Sciences 93, 1008-1024.

Kräutner, H.G. \& Krstić, B. 2006: Geological map of the Carpatho-Balkanides between Mehadia, Oravita, Nis and Sofia. CD-version provided at the 18th Congress of the Carpathian-Balkan Geological Association. Geoinstitut, Belgrade.

Laubscher, H. 1971: Das Alpen-Dinariden-Problem und die Palinspastik der südlichen Tethys. Geologische Rundschau 60, 813-833.

Lenkey, L. 1999: Geothermics of the Pannonian Basin and its bearing on the tectonics of basin evolution. PhD Thesis, Vrije Universiteit Amsterdam, Amsterdam, 215 pp.

Lickorish, W.H. \& Ford, M. 1998: Sequential restoration of the external Alpine Digne thrust system, SE France, constrained by kinematic data and synorogenic sediments. In: Mascle, A., Puidgefàbregas, C., Luterbacher, H.P. \& Fernàndez, M. (Eds.): Cenozoic Foreland Basins of Western Europe, Geological Society London Special Publication 134, 189-211.

Linzer, H.-G., Decker, K., Peresson, H., Dell>Mour, R. \& Frisch, W. 2002: Balancing lateral orogenic float of the Eastern Alps. Tectonophysics 354, 211-237.

Lippitsch, R., Kissling, E. \& Ansorge, J. 2003: Upper mantle structure beneath the Alpine orogen from high-resolution teleseismic tomography. Journal of Geophysical Research 108(B8), 2376, doi:10.1029/2002JB002016.

Means, W. 1989: Stretching faults. Geology 17, 893-896.

Márton, E. 2000: The Tisza Megatectonic Unit in the light of paleomagnetic data. Acta Geologica Hungarica 43/3, 329- 343.

Márton, E. \& Fodor, L. 1995: Combination of palaeomagnetic and stress data - a case study from North Hungary. Tectonophysics 242, 99-114. 
Márton, E. \& Fodor, L. 2003: Tertiary paleomagnetic results and structural analysis from the Transdanubian Range (Hungary): rotational disintegration of the ALCAPA unit. Tectonophysics 363, 201-224.

Márton, E. \& Márton, P. 1996: Large scale rotations in North Hungary during the Neogene as indicated by palaeomagnetic data. In: Morris, A. \& Tarling, D.H. (Eds.): Palaeomagnetism and Tectonics of the Mediterranean Region, Geological Society London Special Publication 105, 153-173.

Márton, E., Pavelić, D., Tomljenović, B., Avanić, R., Pamić, J. \& Márton, P. 2002: In the wake of a counter-clockwise rotating Adriatic microplate: Neogene paleomagnetic results from northern Croatia. International Journal of Earth Sciences 91, 514-523.

Márton, E., Drobne, K., Ćosović, V. \& Moro, A. 2003: Paleomagnetic evidence for Tertiary counterclockwise rotation of Adria. Tectonophysics 377, $143-156$.

Márton, E., Tischler, M., Csontos, L., Fügenschuh, B. \& Schmid, S.M. 2007: The contact zone between the ALCAPA and Tisza-Dacia mega-tectonic units of Northern Romania in the light of new paleomagnetic data. Swiss Journal of Geosciences 100,109-124.

Mason, P.R.D., Seghedi, I., Szakacs, A \& Downes, H. 1998: Magmatic constraints on geodynamic models of subduction in the Eastern Carpathians, Romania. Tectonophysics 297, 157-176,

Matenco, L. \& Bertotti, G. 2000: Tertiary tectonic evolution of the external East Carpathians (Romania). Tectonophysics 316, 255-286.

Matenco, L., Bertotti, G., Dinu, C. \& Cloetingh, S. 1997: Tertiary tectonic evolution of the external South Carpathians and the adjacent Moesian platform (Romania). Tectonics 16, 896-911.

Matenco, L., Bertotti, G., Cloetingh, S. \& Dinu, C. 2003: Subsidence analysis and tectonic evolution of the external Carpathian-Moesian Platform region during Neogene times. Sedimentary Geology 156, 71-94.

Matenco, L., Bertotti, G., Leever, K., Cloetingh, S., Schmid, S.M., Tarapoanca, M. \& Dinu, C. 2007: Large-scale deformation in a locked collisional boundary: Interplay between subsidence and uplift, intraplate stress, and inherited lithospheric structure in the late stage of the SE Carpathians evolution. Tectonics 26/4, TC4011, doi:10.1029/2006TC001951.

Mikes, T., Dunkl, I., von Eynatten, H., Báldi-Beke, M. \& Kázmer, M. 2008: Calcareous nannofossil age constraints on Miocene flysch sedimentation in the Outer Dinarides (Slovenia, Croatia, Bosnia-Hercegovina and Montenegro). In: Siegesmund, S., Fügenschuh, B. \& Froitzheim, N. (Eds.): Tectonic aspects of the Alpine-Dinaride-Carpathian System, Geological Society London Special Publications 298, 335-363.

Morley, C.K. 1996: Models for relative motion of crustal blocks within the Carpathian region, based on restorations of the outer Carpathian thrust sheets. Tectonics 15, 885-904.

Moser, F. 2001: Tertiäre Deformation in den rumänischen Südkarpathen: Strukturelle Analyse eines Blattverschiebungskorridors am Westrand der mösischen Plattform. Tübinger Geowissenschaftliche Arbeiten, Reihe A, 63, Tübingen, $169 \mathrm{pp}$

Nagymarosy, A. \& Müller, P. 1988: Some aspects of Neogene biostratigraphy in the Pannonian Basin. In: Royden, L.H. \& Horváth, F. (Eds.): The Pannonian Basin. A Study in Basin evolution, AAPG Memoir, 45. The American Association of Petroleum Geologists and the Hungarian Geological Society, Budapest, Hungary, 69-77.

NOAA, 1988. Data Announcement 88-MGG-02, NOAA National Geophysical Data Center, Digital relief of the Surface of the Earth. http://www. ngdc.noaa.gov/mgg/global/etopo5.html, Boulder, Colorado.

Nussbaum, C. 2000: Neogene tectonics and thermal maturity of sediments of the easternmost Southern Alps (Friuli Area, Italy). PhD Thesis, Université de Neuchâtel, Neuchâtel, 172 pp.

Oszczypko, N. 2006: Late Jurassic-Miocene evolution of the Outer Carpathian fold-and-thrust belt and its foredeep basin (Western Carpathians, Poland). Geological Quarterly 50,169-194.

Pamić, J. 1993: Eoalpine to Neoalpine magmatic and metamorphic processes in the northwestern Vardar Zone, the easternmost Periadriatic Zone and the southwestern Pannonian Basin. Tectonophysics 226,503518.

Pamić, J. 2002: The Sava-Vardar Zone of the Dinarides and Hellenides versus the Vardar Ocean. Eclogae Geologicae Helvetiae 95, 99-113.
Patrascu, S., Panaiotu, C., Seclaman, M. \& Panaiotu, C.E. 1994: Timing of rotational motion of Apuseni Mountains (Romania) - Paleomagnetic data from Tertiary magmatic rocks. Tectonophysics 233,163-176.

Philippe, Y., B. Colletta, E. Deville, and A. Mascle, The Jura fold-and-thrust belt: a kinematic model based on map-balancing. In Horvath F. (Ed.): Structure and prospects of Alpine Basins and Forelands; Peri-Tethys Memoir 2. Mémoires du Musée National de l'Histoire de la Nature Paris $170,235-261$.

Picha, F.J. 2002: Late orogenic strike-slip faulting and escape tectonics in the frontal Dinarides-Hellenides, Croatia, Yugoslavia, Albania, and Greece. AAPG Bulletin 86, 1659-1671.

Piromallo, C. \& Morelli, A. 2003: P wave tomography of the mantle under the Alpine-Mediterranean area. Journal of Geophysical Research 108 (B2), doi:10.1029/2002JB001757.

Ratschbacher, L., Frisch, W., Linzer, H.-G. \& Merle, O. 1991: Lateral extrusion in the Eastern Alps; Part 2, Structural analysis. Tectonics 10, 257-271.

Roca, E., Bessereau, G., Jawor, E., Kotarba, M. \& Roure, F. 1995: Pre-Neogene evolution of the Western Carpathians: Constraints from the Bochnia-Tatra Mountains section (Polish Western Carpathians). Tectonics 14, 855-873.

Roure, F., Roca, E. \& Sassi, W. 1993: The Neogene evolution of the outer Carpathian flysch units (Poland, Ukraine and Romania): kinematics of a foreland/fold-and-thrust belt system. Sedimentary Geology 86,177-201.

Royden, L.H. 1988: Late Cenozoic tectonics of the Pannonian Basin system. In: Royden, L.H. \& Horváth, F. (Eds.): The Pannonian Basin. A Study in Basin evolution, AAPG Memoir, 45. The American Association of Petroleum Geologists and the Hungarian Geological Society, Budapest, Hungary, 27-48.

Royden, L.H., Horváth, F. \& Rumpler, J. 1983: Evolution of the Pannonian Basin System 1. Tectonics. Tectonics 2, 63-90.

Royden, L.H. \& Báldi, T. 1988: Early Cenozoic tectonics and Paleogeography of the Pannonian and surrounding regions. In: Royden, L.H. \& Horváth, F. (Eds.): The Pannonian Basin. A Study in Basin evolution, AAPG Memoir, 45. The American Association of Petroleum Geologists and the Hungarian Geological Society, Budapest, Hungary, 1-16.

Royden, L.H. \& Burchfiel, B.C. 1989: Are systematic variations in thrust belt style related to plate boundary processes? (The Western Alps versus the Carpathians). Tectonics 8, 51-61.

Saftić, B., Velić, J., Sztanó, O., Juhász, G. \& Ivković, Ž. 2003:Tertiary subsurface facies, source rocks and hydrocarbon reservoirs in the SW part of the Pannonian Basin (Northern Croatia and South-Western Hungary). Geologia Croatica 56, 101-122.

Săndulescu, M., Kräutner, H.G., Borcos, M., Năstăseanu, S., Patrulius, D., Stefănescu, M., Ghenea, C., Lupu, M., Savu, H., Bercia, I. \& Marinescu, F. 1978: Geological map of Romania 1:1.000.000. Institut de Géologie Roumain, Bucharest.

Săndulescu, M. 1988: Cenozoic tectonic history of the Carpathians. In: Royden, L.H. \& Horváth, F. (Eds.): The Pannonian Basin. A Study in Basin evolution, AAPG Memoir, 45. The American Association of Petroleum Geologists and the Hungarian Geological Society, Budapest, Hungary, 17-25.

Schmid, S.M., Aebli, H.R. \& Zingg, A. 1989: The role of the Periadriatic Line in the tectonic evolution of the Alps. In: Coward, M.P., Dietrich, D. \& Park, R.G. (Eds.): Alpine Tectonics, Geological Society London, Special Publication 45, 153-171.

Schmid, S.M., Pfiffner, O.A., Froitzheim, N., Schönborn, G. \& Kissling, E. 1996: Geophysical-geological transect and tectonic evolution of the Swiss-Italian Alps. Tectonics 15, 1036-1064.

Schmid, S.M., Berza, T., Diaconescu, V., Froitzheim, N. \& Fügenschuh, B. 1998: Orogen-parallel extension in the Southern Carpathians. Tectonophysics 297, 209-228.

Schmid, S.M. \& Kissling, E. 2000: The arc of the western Alps in the light of geophysical data on deep crustal structure. Tectonics 19, 62-85.

Schmid, S.M., Fügenschuh, B., Kissling, E. \& Schuster, R. 2004a: Tectonic map and overall architecture of the Alpine orogen. Eclogae Geologicae Helvetiae $97,93-117$.

Schmid, S.M., Fügenschuh, B., Kissling, E. \& Schuster, R. 2004b:TRANSMED Transects IV, V and VI: Three lithospheric transects across the Alps and their forelands. In: Cavazza, W., Roure, F., Stampfli, G.M. \& Ziegler, P.A. 
(Eds.): The TRANSMED Atlas: The Mediterranean Region from Crust to Mantle. Springer, Berlin, Heidelberg.

Schmid, S.M., Bernoulli, D., Fügenschuh, B., Matenco, L., Schuster, R., Schefer, S., Tischler, M. \& Ustaszewski, K. 2008: The Alpine-CarpathianDinaridic orogenic system: correlation and evolution of tectonic units. Swiss Journal of Geosciences 101,139-183.

Schönborn, G. 1992: Alpine tectonics and kinematic models of the central Southern Alps. Memorie di Scienze Geologiche, Istituti di Geologia e Mineralogia dell' Universita di Padova XLIV, 229-393.

Schönborn, G. 1999: Balancing cross sections with kinematic constraints: The Dolomites (northern Italy). Tectonics 18, 527-545.

Sclater, J., Royden, L., Horvath, F., Burchfiel, B., Semken, S. \& Stegena, L. 1980: The formation of the intra-Carpathian basins as determined from subsidence data. Earth and Planetary Science Letters 51,139-162.

Seghedi, I., Balintoni, I. \& Szakács, A. 1998: Interplay of tectonics and neogene post-collisional magmatism in the intracarpathian region. Lithos 45 , 483-497.

Sperner, B., Ratschbacher, L. \& Nemcok, M. 2002: Interplay between subduction retreat and lateral extrusion: tectonics of the Western Carpathians. Tectonics 21(6), 1051, doi:10.1029/2001TC901028.

Sperner, B. \& CRC 461 Team 2005: Monitoring of Slab Detatchment in the Carpathians. In: Wenzel F (Ed): Perspectives in modern Seismology. Lecture Notes in Earth Sciences 105, 187-202.

Stampfli, G.M. \& Borel, G.D. 2004: The TRANSMED transects in space and time: constraints on the paleotectonic evolution of the Mediterranean domain. In: Cavazza, W., Roure, F.M., Spakman, W., Stampfli, G.M. \& Ziegler, P.A. (Eds.): The TRANSMED Atlas: The Mediterranean Region from Crust to Mantle. Springer, Berlin and Heidelberg, 5380 .

Steininger, F.F. \& Wessely, G. 1999: From the Tethyan Ocean to the Paratethys Sea: Oligocene to Neogene Stratigraphy, Paleogeography and Paleobiogeography of the Circum-Mediterranean region and the Oligocene to Neogene Basin evolution in Austria. Mitteilungen der Österreichischen Geologischen Gesellschaft 92, 95-116.

Stipp, M., Fügenschuh, B., Gromet, L.P., Stünitz, H. \& Schmid, S.M. 2004: Contemporaneous plutonism and strike-slip faulting: A case study from the Tonale fault zone north of the Adamello pluton (Italian Alps). Tectonics 23: TC3004, doi:10.1029/2003TC001515.

Strauss, P., Wagreich, M., Decker, K. \& Sachsenhofer, R.F. 2001: Tectonics and sedimentation in the Fohnsdorf-Seckau Basin (Miocene, Austria): from pull-apart basin to a half-graben. International Journal of Earth Sciences 90, 549-559.

Szafián, P., Tari, G., Horváth, F. \& Cloetingh, S. 1999: Crustal structure of the Alpine-Pannonian transition zone: a combined seismic and gravity study. International Journal of Earth Sciences 88, 98-110.

Tari, G.C. 1996: Extreme crustal extension in the Rába River extensional corridor (Austria/Hungary). In: Decker, K. (Ed.): PANCARDI workshop 1996. Dynamics of the Pannonian-Carpathian-Dinaride system, Lindabrunn, Austria. Mitteilungen der Gesellschaft der Geologie- und Bergbaustudenten in Österreich 41,1-17.

Tari,V.2002: Evolution of the northern and western Dinarides: a tectonostratigraphic approach. EGU Stephan Mueller Special Publication Series 1, 223-236.

Tischler, M. 2005: A combined structural and sedimentological study of the Inner Carpathians at the northern rim of the Transylvanian Basin (North Romania). PhD Thesis, University Basel, Basel, 124 pp.
Tischler, M., Gröger, H., Fügenschuh, B. \& Schmid, S.M. 2007: Miocene tectonics of the Maramures area (Northern Romania): implications for the Mid-Hungarian fault zone. International Journal of Earth Sciences 96, 473-496.

Tomljenović, B. 2000: Zagorje - Mid-Transdanubian zone. In: Pamić, J. \& Tomljenović, B. (Eds.): PANCARDI 2000 Fieldtrip Guidebook, Dubrovnik. Vijesti Hrvatskog geološkog društva, 37/2, 27-33.

Tomljenović, B. 2002: Strukturne Znacajke Medvednice i Samoborskoj gorja (in Croatian, translated title: Structural characteristics of Medvednica and Samoborsko gorje Mts.). PhD Thesis, Zagreb University, Zagreb, 208 pp.

Tomljenović, B. \& Csontos, L. 2001: Neogene-Quaternary structures in the border zone between Alps, Dinarides and Pannonian Basin (Hrvatsko Zagorje and Karlovac Basins, Croatia). International Journal of Earth Sciences 90, 560-578.

Tomljenović, B., Csontos, L., Márton, E. \& Márton, P. 2008: Tectonic evolution of the northwestern Internal Dinarides as constrained by structures and rotation of Medvednica Mts., North Croatia. In: Siegesmund, S., Fügenschuh, B. \& Froitzheim, N. (Eds.): Tectonic aspects of the AlpineDinaride-Carpathian System, Geological Society Special Publication 298, 145-168.

Ustaszewski, K., Schmid, S.M., Lugović, B., Schuster, R., Schaltegger, U., Bernoulli, D., Hottinger, L., Kounov, A., Fügenschuh, B. \& Schefer, S. submitted: Late Cretaceous intra-oceanic magmatism in the Internal Dinarides (northern Bosnia and Herzegovina): Implications for the collision of the Adriatic and European plates. Lithos special issue "Balkan Ophiolites", A. Robertson, S. Karamata, K. Resimić-Šarić (Eds.).

van Hinsbergen, D., Hafkenscheid, E., Spakman, W., Meulenkamp, J.E. \& Wortel, R. 2005: Nappe stacking resulting from subduction of oceanic and continental lithosphere below Greece. Geology 33, 325-328.

Viola, G., Mancktelow, N.S. \& Seward, D. 2001: Late Oligocene-Neogene evolution of Europe-Adria collision: New structural and geochronological evidence from the Giudicarie fault system (Italian Eastern Alps). Tectonics 20, 999-1020.

von Blanckenburg, F. \& Davies, J.H. 1995: Slab breakoff: A model for syncollisional magmatism and tectonics in the Alps. Tectonics 14: 120-131

von Blanckenburg, F., Villa, I.M., Baur, H., Morteani, G. \& Steiger, R.H. 1989: Time calibration of a PT-path from the Western Tauern Window, Eastern Alps: the problem of closure temperatures. Contributions to Mineralogy and Petrology 101,1-11.

Weber, J., Vrabec, M., Stopar, B., Pavlovčič-Prešeren, P. \& Dixon, T. 2006: The PIVO-2003 Experiment: A GPS study of Istria Peninsula and Adria microplate motion, and active tectonics in Slovenia. In: Pinter, N., Grenerczy, G., Weber, J., Stein, S. \& Medak, D. (Eds.): The Adria Microplate: GPS Geodesy, Tectonics and Hazards, NATO Science Series, Series IV: Earth and Environmental Sciences. Springer, 305-320.

Wilson, M. \& Downes, H. 2006: Tertiary-Quaternary intra-plate magmatism in Europe and its relationship to mantle dynamics. In: Gee, D.G. \& Stephenson, R.A. (Eds.): European Lithosphere Dynamics, Geological Society London Memoirs 32,147-166.

Wortel, M.J. R. \& Spakman, W. 2000: Subduction and slab detachment in the Mediterranean-Carpathian region. Science 290, 1910-1917.

Manuscript received March 3, 2008

Revision accepted June 6,2008

Published Online first November 8, 2008

Editorial Handling: Nikolaus Froitzheim \& Stefan Bucher 